\title{
CIVIL WAR OUTCOME, DEMOCRATIZATION, AND ETHNIC SUPPORT
}

\author{
NILS W. METTERNICH \\ UNIVERSITY COLLEGE LONDON
}

\begin{abstract}
What are the conditions under which post-conflict elections take place and (2) why do only few post-conflict elections result in democratic post-conflict orders? This is the main puzzle raised in this paper. The argument is that the decision to stage elections and democratize is highly strategic and depends on the ethnic size of the post-conflict government leader. Especially postconflict leaders with large ethnic support are able to utilize quick post-conflict elections to stabilize and legitimize their political position. However, in the long run the government leaders prefer institutions that maximize their time in office and therefore will hinder full scale democratization. The empirical analysis demonstrates that the timing of elections and democratization depend on the ethnic support of the new government and the civil war outcome.
\end{abstract}

\section{Introduction}

What are the conditions under which post-conflict elections and democratization take place? The notion that democratization can occur after armed conflicts seems paradoxical (Wantchekon, 2004). As Wantchekon (2004) highlights many political theorists not only predict but also recommend autocratic institutions after civil wars. Having experienced the English civil wars, Hobbes (1991) advocates a strong Leviathan to restore a peaceful order. Schumpeter (1976) suggests that his minimalist conception of democracy would only emerge in the existence of political tolerance and a strong state and Huntington (1968) even argues that any form of liberal democracy is simply unattainable in the absence of political order. This theoretical conception might also be the reason why only recently studies have empirically examined the conditions under which post-conflict democratization takes place in more detail (Gurses and David, 2008; Joshi, 2010; Fortna and Huang, 2012; Joshi, 2013; Colaresi, 2014; Durant and Weintraub, 2014; Hartzell and Hoddie, 2015; Armey and McNab, 2015; Huang, 2016; Dresden, 2017).

While much research is dedicated to the investigation of democratic transitions from autocratic order (Lipset, 1959; O’Donnell and Schmitter, 1986; Olson, 1993; Przeworski et al., 2000), fewer

Prepared for the Annual Meeting of the American Political Science Association, August 30-September 2, Boston, MA. 
authors focus on post-conflict democratization. This lack of research is surprising as more recent democratic transition theories consider the non-elites' threat of rebellion as a necessary condition for democratization. For example, in the frameworks of Acemoglu and Robinson (2006) or Boix (2003) rebellion is the consequence of the government's failure to react appropriately to the demands of the non-elites. From this perspective, armed conflict is inherently linked to the democratization struggle of the non-elites and post-conflict democratization should be the natural outcome of nonelite threats.

However, when looking at the empirical data new puzzles arise. The first puzzle is that while Gurses and David (2008) demonstrate that the level of democracy ${ }^{1}$ increases after armed conflicts, this rarely leads to fully democratic institutions (Polity score $\geq 6$ ). Most post-conflict countries become and stay "anocracies", that is countries with a Polity score between -5 and $+5 .^{2}$ This means we observe many competitive autocracies (Levitsky and Way, 2010) which allow for some political competition but fail to implement full democratic institutional reforms. Figure 1 illustrates this finding. The upper panel in Figure 1 shows the percentage of countries holding post-conflict elections. Three years after the armed conflict about 40 percent of the countries held elections and after five years about 50 percent. After six years about 60 percent of the post-conflict countries cast their ballot in national elections after which the rate of further post-conflict elections decreases. This suggests a fairly positive picture of post-conflict democratization as $2 / 3$ of post-conflict countries actually implement elections.

But when looking at the time between the first post-conflict election and the time these countries turn democratic (Polity score $\geq 6$ ), the initial positive impression becomes overshadowed. The lower panel in Figure 1 shows the time between the first post-conflict elections and when a country turns democratic. At the beginning there is a sharp drop representing democratic countries that experienced an armed conflict and stayed democratic afterwards (e.g. United Kingdom, India, or Indonesia). Besides these already pre-conflict democracies not many other countries actually turn democratic after an armed conflict. Figure 1 demonstrates that only 50 percent of the countries that hold post-conflict elections eventually turn democratic in the observed time period (1965-2005).

This empirical puzzle motivates two interrelated research questions. (1) What are the conditions under which post-conflict elections take place and (2) why do only few post-conflict elections result

\footnotetext{
${ }^{1}$ As measured by the Polity IV score.

${ }^{2}$ For an extensive discussion of anocracies compare Epstein et al. (2006)
} 
Figure 1. Left panel: Time until first post-conflict election. Right panel: Time between first post-conflict election and a Polity score $\geq 6$
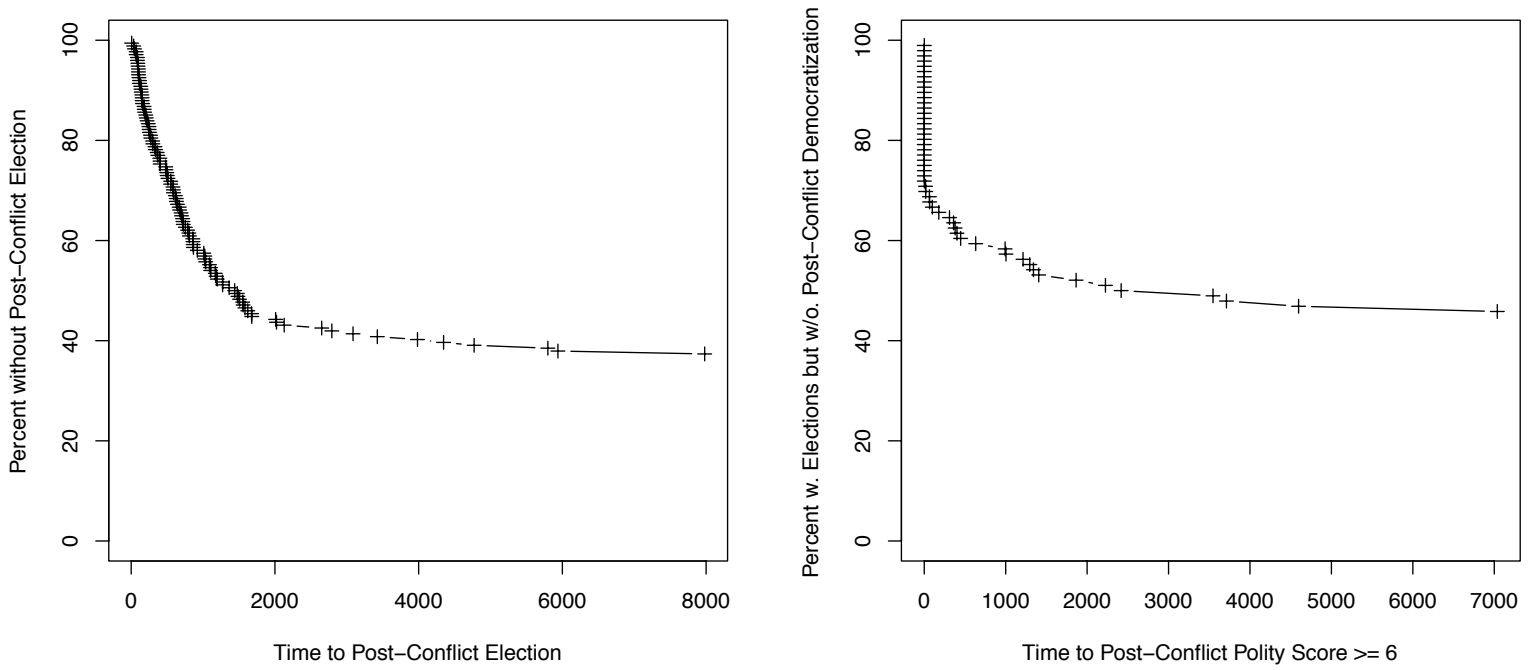

in democratic post-conflict orders? This paper argues that this pattern results from the postconflict government leader's preferences over post-conflict institutions. Especially, post-conflict government leaders with large ethnic support are able to utilize quick post-conflict elections to stabilize and legitimize their political position. However, in the long run the post-conflict leaders prefer institutions that maximize their time in office (Bueno de Mesquita et al., 2003) and therefore will hinder full scale democratization. Therefore, post-conflict government leaders with large ethnic support can leverage their popular backing to secure their short-term political survival but hesitate to implement institutions that endanger their long-term survival in office. Hence, the paper claims that the discrepancy between election timing and democratization stems from the fact that new government leaders with large ethnic support can use elections to legitimize and consolidate their power (Horowitz, 1993). They will favor quick elections to gain domestic and international reputation and support. However, in the longrun they wish to avoid democratization as this yields a higher risk of leadership turnover (Bueno de Mesquita et al., 2003). New leaders with little ethnic support would altogether like to avoid elections and longrun democratization. Even though large scale fraud might gain them the necessary majority, this would not be a credible outcome, thus failing to enhance their legitimacy in office.

The reason to call for quick post-conflict elections can be seen as a response to the to highly unstable post-conflict environment. The warring parties have not fully demobilized and splinter 
groups are likely to challenge the new government. Under these circumstances it is crucial to secure the short-run political survival but also build the foundation for a long tenure. Hence, I argue that the end of a civil war is a great opportunity for post-conflict government leaders to engage in what Riker (1986) called "heresthetic" behavior. More precisely, in line with Riker's ideas, post-conflict leaders will seek to influence the set of relevant agents in a political system, invent new actions, alter actor preferences, and invent political processes.

In this paper, I extend work that has begun to explore the relationship between civil war outcome and post-conflict democratization (Gurses and David, 2008; Joshi, 2010; Fortna and Huang, 2012; Joshi, 2013; Colaresi, 2014; Durant and Weintraub, 2014; Hartzell and Hoddie, 2015; Armey and McNab, 2015; Huang, 2016; Dresden, 2017). The empirical analysis demonstrates that the timing of elections depends on the ethnic support of the new government, whereas full democratic reforms not only depend on the ethnic support of the new leader but also on the outcome of the civil war. Rebel leaders with large ethnic support are not only more likely to stage elections but also to implement democratic institutions.

This paper is organized as follows. I shortly review the democratization literature and highlight the link between post-war democratization and armed conflict. In the theoretical section I present an argument that explains the strategic choice of post-war institutions as a result of the interaction between the new government leader and his/her supporters. The presentation of the empirical results are followed by a concluding section discussing insights and limitations of this study as well as possible extensions.

\section{LiteratuRE REVIEW}

2.1. Democratization. This paper draws from two important political science literatures: the democratic transition and the civil war research. The democratization literature entails two broad approaches. One line of research investigates the impact of "good institutions" on economic development and how institutional constraints impact on investment decisions (e.g., Knack and Keefer (1995); Besley (1995); Barro (1997)). This line of research treats existing institutions as fixed and investigates equilibria behavior within them.

In contrast, the other research approach tries to endogenize institutions and understands them as equilibrium outcomes of economic development and inequality (Lipset, 1959; Przeworski, 1991; Greif and Laitin, 2004; Acemoglu and Robinson, 2006). This literature argues that democratization is an equilibrium outcome of the strategic interaction between rich rulers and poor ruled (Geddes, 
2007). In this context, Boix (2003) develops a theoretical argument that income equality and capital mobility reduce elite fears of democracy because it decreases their expected costs of political transition. Acemoglu and Robinson (2006) model democratization as an opportunity for the rich political elite to mitigate commitment problems in times of weakness. However, one limitation of these approaches stressing the elite-poor interaction is that democratization is a strictly bottomup process (Houle, 2009). An alternative perspective analyzes democratization as an equilbrium outcome of political competition and includes a horizontal dimension (Przeworski, 1991, 2005). Przeworski (1991) argues that democratic systems can only be sustained if the value of electoral competition is greater than the expected value of a dictatorship. This implies that democracy can only prosper if electoral defeated actors have reasonable prospects to regain power in the future. In a slight revision of this argument, Przeworski (2005) suggests that in poor countries such prospects are neither sufficient nor necessary conditions for democracy, since even groups that have a good chance of winning in a democracy may want to monopolize power. Moreover, Bueno de Mesquita et al. (2003) suggest that the political leadership should never have an interest in democratization because it decreases their prospects of staying in office. Increasing the size of the selectorate and decreasing the winning coalition at the same time is generally seen as a way to prolong political survival. Therefore, only constraints by supporters or political competition from challengers might pressure the leadership into democratic institutions. Hence, democratic institutions cannot solely be explained by the preferences of the political leadership but by analyzing the interaction between the elites, non-elites (Acemoglu and Robinson, 2006), and possible challengers (Przeworski, 2005).

2.2. Civil War and Democratization. The relationship between civil war and democratization has mainly been investigated by conceptualizing democratization as an explanatory variable and analyzing its effect on civil war. This research has generated important insights about the relationship of democratization and civil war onset (Hegre et al., 2001; Reynal-Querol, 2005; Gleditsch, 2007). But far less research has treated civil war as an explanatory variable and looked at its effect on democratization or post-war institutions (Wantchekon, 2004; Gurses and David, 2008). Nonetheless, what has been intensely investigated are civil war characteristics that explain postconflict peace duration (Walter, 2004; Fortna, 2004; Doyle and Sambanis, 2000). For example, Doyle and Sambanis (2000) suggest that peace-keeping operations during war help to sustain peace and foster democracy. In addition, Hartzell and Hoddie (2003) condition peace duration on the outcome of civil wars arguing that the more extensive power-sharing agreements are incorporated 
into settlement agreements, the more likely peace endures. Finally, Mukherjee (2006) claims that power-sharing agreements are more stable after victories of the government.

In regard to post-war democratization, Wantchekon and Nickerson (1999) show how interventions can lead to higher levels of post-conflict democracy compared to pre-conflict levels. Wantchekon (2004) theoretically approaches the puzzle why democratic regimes can arise after civil war and argues that citizens can have an arbitration role at the end of a conflict, which can help elites to settle for a democratic post-war order. A study that is closely related to this paper is by Gurses and David (2008) who explain post-war democratization by the outcome of war. They argue that elites chose democratic institutions as part of peace settlements, because democracy might be a way to restore order while constraining the ability of the opponent to revert to political violence. In the following, I argue that while the civil war literature has strongly focused on the interaction between the leaders of the warring parties, it underestimates the role of the leaders' supporters. The insight of the democratic transition literature that political leaders choose institutions based on the characteristics and preferences of their supporters has not fully been incorporated in existing civil war theories. Therefore, this paper stresses the importance of supporter characteristics and the interaction between the political leadership, their followers, and possible challengers.

2.3. Ethnicity, Elections, and Democratization. The theoretical section of this paper will argue that ethnicity is an important characteristic of government and rebel supporters that conditions their leaderships' institutional choice. The relationship between ethnicity and democracy is often viewed as conflictual. For example, Horowitz (1993) argues that ethnic conflict is a major reason why democratization failed in many African, Asian, East European, and former Soviet Union countries. Furthermore, he argues that even if a coalition of ethnic groups toppled the old authoritarian regime, the new leader often peals away from the multi-ethnic party that supported him/her as soon as s/he was in office. The new post-conflict leader frequently tries to establish a new group of supporters of his/her own ethnic group and excludes members of other ethnic groups. What is important about this observation is that even though ethnic lines are indeed transcendable, they nonetheless provide politically significant cleavages in first (Bratton and van de Walle, 1997) and post-conflict elections (Collier, 2009). Horowitz (1993) also highlights that free and fair elections can be utilized by large ethnic groups to permanently exclude smaller groups from political power. This point is also stressed by Sisk (1996:31) who suggests that: 
...in many divided societies, electoral competition is a contest for ownership of the state. Minorities, particularly, equate democracy not with freedom or participation but with the structural dominance of adversarial majority groups. Permanent minorities... have feared the consequences of electoral competitions, especially when the expected consequence of majority victory is discrimination against them. For minority groups, losing an election is a matter not simply of losing office but of losing the means for protecting the survival of the group.

And also Linz and Stepan (1996:29) argue that multinational, multilingual, and multicultural states have more complex politics and it will eventually be more difficult to agree on the fundamentals of democracy. Especialy, if multiple ethnicities are salient and conflicts are polarized along ethnic lines democratization is believed to be difficult if not impossible. This contrast to a certain extent with findings of Ordeshook and Shvetsova (1994) which demonstrate that proportionality systems fail to produce multiple parties in ethnically homogenous and not heterogenous societies. Even though the arguments and findings slightly vary, there is a broad support for the notion that ethnic cleavages impact on a country's political institutions (Mozaffar, Scarritt and Galaich, 2003). While the following argument does not suggest that ethnicity is a stumbling block for democratization per-se, it outlines more precise conditions under which ethnic support increases or decreases the probability of post-conflict elections and democratization.

This paper argues that ethnicity is an important factor to explain the institutional choices post-conflict leaders make. It thereby follows Riker's notion that politicians want to manipulate institutions in their favor by influencing the set of actors, inventing actions, altering incentives, and creating political processes. This incorporates the idea that institutional change results from deliberate political strategies to transform structural parameters in order to win long-term political advantage (Thelen and Steinmo, 1992). That politicians seek to change institutions in their favor is no surprise as we have empirical evidence that electoral systems have a huge impact on who can enter, win, and lose political contests (Cox, 1997). The strategic role of electoral institutions is well established in the literature (Taagepera and Shugart, 1989; Lijphart, 1994; Sartori, 1994) and the work of Cox (1997) clarifies the central logic that: (a) candidates wish to get elected and voters want to benefit from their vote choice, and (b) the candidates' and voters' expectation of winning or losing are mutually reinforcing. 


\section{THEORY}

3.1. Intuition. Post-conflict environments are extremely unstable and post-conflict government leaders are confronted with the challenge to consolidate their power. The theoretical section of this paper argues that post-conflict government leaders can utilize elections and democratization to gain domestic and international legitimacy and thereby strengthen their political position. Winning post-war elections signals to potential challengers that the new government has popular support. This increases the expected costs of toppling the new leader because recruitment costs increase and potential challengers are more likely to be detected. In addition, post-conflict elections send a signal to the international community that the new government is on the road to democratization, which attracts international recognition. This again increases the costs of rebellion for potential challengers because the new government is likely to attain international support in an armed conflict. However, staging elections quickly after the war entails the risk of losing power and clearly rigged elections may cause domestic unrest and international contempt. For example, Afghanistan's president Karsai faced great international pressure after results of the 2010 election were apparently rigged. This implies that post-conflict elections are only a feasible strategy for government leaders who enjoy sufficient popular support to win free and fair elections or and for those that only need to engage in minor manipulations to decide the electoral contest.

While the theoretical section highlights that post-war elections are beneficial to new government leaders with large ethnic support, it casts doubts to whether this also holds for democratization. For example, Bueno de Mesquita et al. (2003) suggest that government leaders should have an interest in institutions with large selectorates and small winning coalitions to guarantee their long term political survival. This implies that new leaders should oppose democratic institutions if possible. Similarly, Acemoglu and Robinson (2006) argue that the political elite will only implement democratic institutions in times of weakness to avoid a challenge by the poor. They provide evidence that democratic institutions can serve as a credible commitment device for the political elite. Boix (2003) also claims that the political elite will only democratize if certain economic conditions are met (relative equality and capital mobility). I argue that the decision of post-war government leaders to democratize is a function of their ethnic support and whether they were pre-conflict incumbents or rebel leaders. Incumbents that are able to defend their office successfully have little incentives to democratize, as they survived with the support of their existing winning coalition. However, rebel leaders that successfully gained office have not yet established a winning coalition 
that will enable them to rule the state. Additionally, their supporters fought against the elite to change the political system in their favor, which frequently entails the demand for credible economic redistribution (Boix, 2003) and access to political power (Acemoglu and Robinson, 2006).

\subsection{Assumptions.}

3.2.1. Actors and Preferences. The theoretical section introduces four actors. An incumbent leader holding office and a challenger to the government. In addition, each political leader has a group of supporters that supply the necessary forces to compete in an armed conflict. On the incumbent side the group that organizes the support for the government are the members of the pre-conflict winning coalition. In a military dictatorship the winning coalition would entail the top-ranking generals, while in a one-party system it would be comprised of the top party officials. On the challenger side the supporters are the politically excluded non-elites that seek political representation and economic redistribution.

In line with the theoretical approach by Bueno de Mesquita et al. (2003), I assume that both the incumbent and the challenger are most interested in their political survival. This implies that any post-conflict leader will try to implement institutions that increase their probability of remaining in office. However, what distinguishes the challenger and the incumbent are the constraints set by their supporters. Remember that the incumbent's supporters are part of the political elite, while the challenger's supporters are representing the politically and economically excluded non-elites of a country. Because the incumbent's supporters are already part of the existing winning coalition, they prefer the status quo over any political change that could diminish their political power and the private goods they are receiving from the government. The challenger's supporters, on the other hand, strive for credible political representation and a greater redistribution of wealth and therefore prefer democratic post-war institutions.

3.2.2. Actions and Payoffs. Having defined the actors and their preferences, I now define the actors' actions within the theoretical framework. I assume that any new government leader, successful challenger or incumbent, has five choices.

\section{Leaders' possible actions:}

(a) Stage manipulated elections but do not democratize

(b) Stage manipulated elections and push for democratization

(c) Stage free and fair elections but do not democratize

(d) Stage free and fair elections and push for democratization

(e) Neither organize elections nor democratize the country 
I assume that the payoffs to each of the outcomes depends on the ethnic support of the new government leader independent of whether it is the incumbent or a successful challenger. Recall that winning post-war elections signals to potential challengers that the new government has significant popular support. This increases the expected costs of toppling the new leader because recruitment costs increase and potential challengers are more likely to be detected. Recruitment costs increase because the pool of potential recruits becomes smaller as the number of government supporters increases. In addition, post-war elections send a signal to the international community that the new government is on the road to democratization, which attracts international recognition. This again increases the costs of rebellion for potential challengers because the new government is likely to attain international support in an armed conflict. Therefore, the expected utility of free and fair elections increases, the more ethnic support the new government leader has.

Because successful elections are a formidable signal to domestic and international audiences, we would suspect that there are incentives to manipulate this signal by committing election fraud if the ethnic support is not sufficient to win in free and fair elections. However, there are certain costs to the detection of election fraud and the risk of detection increases with the scale of the manipulation. Election fraud can severely damage the international reputation of the new government leader, which diminishes his/her international backing and makes him/her more vulnerable to domestic challengers. For example, Afghanistan's president Karsai is accused of large scale election fraud that left him in an extremely weak position. If we assume that the risk of detection increases with the scale of manipulation, we can conclude that new leaders with small ethnic support will refrain from election fraud and therefore any form of election.

I now turn to the action set of the supporters. The supporters of the new government leader can strategically react to their leaders' actions by either sustaining or withdrawing their support.

\section{Supporters' possible actions:}

(a) Supporting their leader's action

(b) Withdrawing their support and implement their preferred institutions

If the supporters withdraw their support they can implement their preferred institutions, which comes at the cost of destabilizing their leadership. Because supporters of large ethnic groups can be relatively certain to win elections anyways, they are less dependent on their leadership to be successful at the ballot box. But especially small and medium sized ethnic groups are more dependent on their leadership and might lose essential votes without a clear leadership that can solve collection action problems among group members. These groups face a tradeoff between 
removing their leader and risking political defeat or keeping a leader which might not implement the preferred institutions but who at least provides private goods to the group.

3.3. Strategic outcomes. I now establish the conditions under which new government leaders choose to stage elections and democratize. The first proposition is that new government leaders with low ethnic support are highly unlikely to stage elections. I rest this proposition on two arguments. The first argument is that because government leaders are interested in their political survival, they are very unlikely to call for free and fair elections when they are likely to lose them. In cases where the new leader has low ethnic support this is exactly the case. Even though postconflict elections are not always determined by ethnic configuration, there is empirical evidence that ethnicity is a major component of success in first elections (Bratton and van de Walle, 1997; Horowitz, 1993). Therefore, new government leaders with low ethnic support should never support elections. Nonetheless, as outlined above, there are benefits to successful elections because they increase the expected costs of challenging the new government. So there might be incentives for the new government to manipulate elections and commit fraud. However, there are also costs associated the election fraud. If the manipulation is detected, the result is not a very convincing domestic signal for support and it might even lead to an international delegitimization. Especially, leaders with low ethnic support have to engage in large scale and hence easier detectable election fraud. Therefore, with decreasing ethnic support, there are diminishing returns to election fraud. This means that even if leaders have the option to manipulate post-conflict elections, they will not do so if their support is very limited. This leads to the proposition that new government leaders with low ethnic support will always avoid post-war elections.

Proposition 1: Post-conflict leaders with low ethnic support do not stage postconflict elections.

However, in this setup elections can result from two different processes. Either elections are solely a strategic decision to consolidate power or they are additionally carried out to achieve democratization in the long run. Propositions 2 and 3 state that because challengers and incumbents face different constraints from their support base, the strategic outcome over democratization differs for these types of leaders. The propositions rest on the assumption that government leaders would generally like to avoid democratic systems as they increase the probability of leadership turnover and thus diminish the chances of political survival (Bueno de Mesquita et al., 2003). This implies that independent of whether the new government leader preferred initial post-conflict election or not, 
s/he will always prefer non-democratic institutions that guarantee longer term periods. Indeed, in the case the incumbent stays in power s/he will always achieve this goal because his/her supporters are members of the pre-conflict winning coalition that would like to keep their revenue of private goods. Therefore, there are no conflicting interests between the incumbent and his supporters in regard to preferences over post-conflict institutions.

Proposition 2: Successful incumbents avoid democratic post-conflict institutions independent of their ethnic support.

The supporters of the challenger on the other hand prefer democratic institutions. They have been excluded from political power and economic redistribution and seek institutions that will improve their status. If the challenger enters the government, she would like to opt for nondemocratic institutions to secure her political survival. However, in the challenger's case the new leader faces supporters that threaten to withdraw their support if democratization does not take place. The question is whether the supporter's threat to turn away from their leader is credible. Let us for a moment assume that the supporters come from the same ethnic groups as the rebel leader. If the challenger and her supporters come from a large group and the leader decides not to democratize the threat of withdrawal is credible. The supporters can withdraw their support and install a new leader that is more likely to push for democratic institutions. But what happens if the challenger and her supporters come from a small ethnic group? In this case the threat of of the supporters is not very credible. If the supporters destabilize their leadership and additionally have low ethnic support, this could help the ousted incumbent to regain power. This would imply that a non-democratic order becomes very likely and they would again be excluded from economic and political power. In case they keep their original leader, they would at least gain some benefits from private goods and avoid outright discrimination. The mechanism is similar to the argument in Padró i Miquel (2007), who argues that supporters prefer a predatory leader of their own ethnic group over a leader from another group because they can at least extract some of the private goods. Thus, supporters of the challenger will only demand election if they are members of a large ethnic group.

Proposition 3: Successful challengers avoid democratic post-conflict institutions if their ethnic support is low but choose to democratize if their support is large.

3.4. Hypotheses. The main insight of the theoretical analysis is that the decision to call for elections and/or democratize depends on the new government leader's ethnic group size and whether 
s/he was the incumbent or the challenger during the armed conflict. Post-conflict leaders with low ethnic support are unlikely to stage any form of elections but as their ethnic support increases leaders are more likely to call for elections. They can utilize election to quickly consolidate their power and increase the expected costs of ousting them from office.

Hypothesis 1: The time between the end of a conflict and post-conflict elections decreases as the ethnic support of the new government leaders increases.

But how does the decision to stage elections translate into the decision to democratize a country? At this point the theoretical argument suggests to distinguish between challengers and incumbents. Even though any new government leader prefers non-democratic post-conflict institutions, they face different constraints by their supporters. The supporters of the incumbents are members of the pre-conflict winning coalition who are interested in keeping their share of private goods and therefore would like to avoid democratization. Hence, there are no conflicting preferences in regard to the post-conflict institutions and the successful incumbent leader is free to choose non-democratic institutions.

Hypothesis 2: The time between the end of a conflict and post-conflict democratic increases if the incumbent successfully defends his government position.

In contrast, supporters of the challenger have joined the rebellion to increase their political and economic access and only democratic institutions will credibly improve the position of the non-elites (Bueno de Mesquita et al., 2003; Acemoglu and Robinson, 2006). In case the successful challenger has sufficient ethnic support she accommodates the demands of her supporters and avoids being toppled from her followers. But if the challenger and her supporters have only limited ethnic support the supporters' threat of withdrawing their support is not credible. Implementing democratic institutions after having removed their leader decreases their chances of winning elections and increases the return of the former incumbent. While a non-democratic government led by the challenger at least increases their share of private goods, a return of the old government would leave them with the pre-conflict status quo.

Hypothesis 3: The time between the end of a conflict and post-conflict democracy decreases as the ethnic support of the successful challenger increases. 


\section{EMPIRICAL MODEL}

To test the main hypotheses, I estimate a series of Cox semi-parametric proportional hazards models as the theoretical model does not imply a particular functional form of the underlying baseline hazard. This leaves the duration dependency unspecified and focuses the empirical analysis on how the covariates shift the baseline hazard. In addition, I estimate a recursive multiple equation probit model with an endogenous dummy regressor (bivariate probit) to assess the endogeneity of the decision to stage election and the decision to implement democratic post-conflict institutions.

4.1. Dependent variables. The empirical section introduces two dependent variables. The first dependent variable measures the time between the end of a civil conflict and the first post-conflict election, while the second dependent variable measures the time between the first post-conflict election and until a country reaches a Polity score $\geq 6 .{ }^{3}$ The data is based on the UCDP conflict termination dataset by Kreutz (2010), the election dataset by Regan, Frank and Clark (2009) ${ }^{4}$, and the Polity IV data. The sample used in this paper contains 140 conflicts in 77 countries in the period from 1975-2005. There are no overlapping conflicts in the dataset. If overlapping conflicts exist, I use the latest end date to measure the time until an election or a Polity Score $\geq 6$ is reached. If a conflict reoccurs in a country before elections or democratization takes place, the cases are coded as right-censored. Comparing this approach to other ways of handling the data results in the most conservative estimates. Hence, the unit of analysis is a country-conflict-day. There are 124185 days in the analysis. Out of the 140 cases 96 (69\%) experience post-war elections but only $49(35 \%)$ reach a Polity score $\geq 6$. The average time between the end of a conflict and post-conflict elections is 1029 days (median $=687$ days), while the average time between the first post-conflict election and until a country reaches a Polity score $\geq 6$ is 2007 days (median=965 days).

In the bivariate probit models the outcome variables are simply collapsed to whether postelections (DV 1) take place and/or a country reaches a Polity score $\geq 6$ after the conflict (DV 2). In all models clustered standard errors account for possible interdependence across the 77 conflict units.

\footnotetext{
${ }^{3}$ Recent studies operationalize democratization as the change in pre- and post-civil war Polity scores (Wantchekon and Neeman, 2002; Gurses and David, 2008). The approach in this paper differs as I am interested in the implementation of fully democratic institutions while controlling for the pre-conflict institutions. Additionally, I prefer to analyze post-conflict elections and democratization in a duration framework as it provides a more flexible approach than measuring the Polity score after a fixed time period.

${ }^{4}$ I combine their indicators for executive and legislative national elections.
} 
FIGURE 2. Distribution of the post-conflict government leaders' ethnic group size

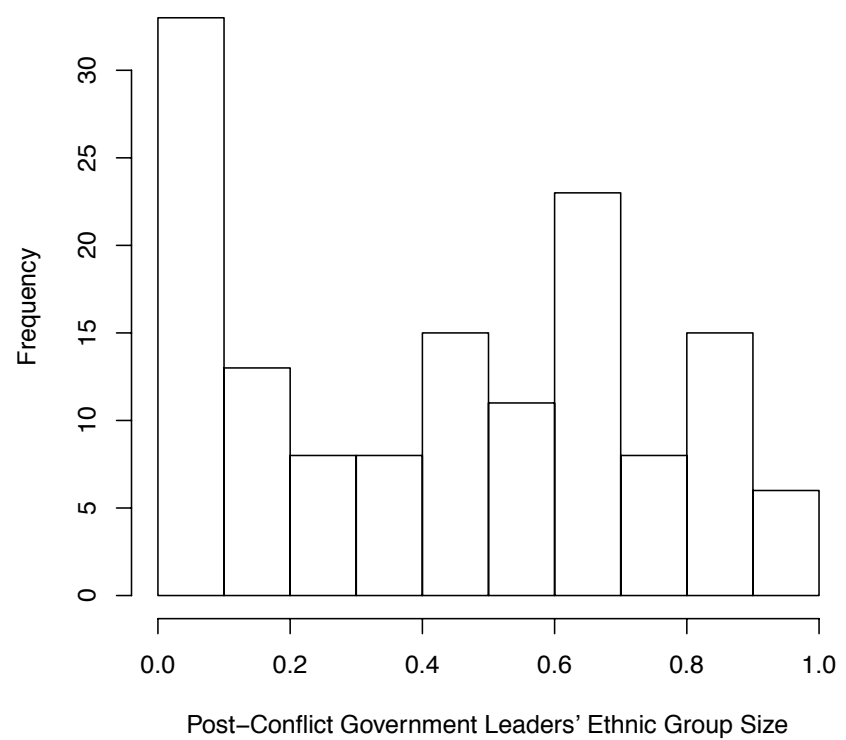

4.2. Explantory variables. The theoretical section pointed to the importance of the post-conflict government leader's ethnic support. In this paper I proxy the ethnic support of the government leader by the size of his/her ethnic group. Data on the post-conflict government leader is taken from the Archigos (version 2.9) data set, which lists all government leaders since 1875 (Goemans, Gleditsch and Chiozza, 2009). To proxy the ethnic support of the post-conflict leader, I use information on the leader's ethnic group provided by Fearon, Kasara and Laitin (2007). Data on the size of the respective ethnic groups is taken from Fearon 2003. Using the size of the leader's ethnic group to proxy his or her ethnic support comes with potential validity problems because we cannot be certain whether the ethnic group is politically relevant (Posner, 2004; Cederman and Girardin, 2007). However, the measure itself is highly reliable in the sense that the measurement criteria are fairly objective. Figure 2 plots the distribution of the post-conflict government leaders' ethnic group size.

The paper's argument highlights that the choice of post-war institutions should not only depend on the new government leader's ethnic group size but also whether s/he is the former incumbent or challenger. I therefore differentiate between government and rebel victories to evaluate whether the incumbent or the challenger gets into office. In addition, I explicitly model the effect of peace agreements, leaving cease fires and low intensity outcomes as residual outcome in the estimated 
models. Information on the outcome of civil conflict is taken from Kreutz (2010). Out of the 140 conflict in the sample 32 end in government victories, 13 in rebel victories and 20 in peace agreements. I leave ceasefires and low-intensity outcomes as the residual category of the analysis.

In order to control for the effects external actors have on election timing and democratization, I include dummy variables for military interventions by democracies, autocracies, and international organizations (IOs). Especially IOs mission mandates frequently state the goal of implementing elections and democratic institutions. Data on international military interventions is taken from Kisangani and Pickering (2007) and Pearson and Baumann (1992) ${ }^{5}$. This intervention data has the advantage of providing start and end dates, as well as differentiating between interventions of states and organizations. I generate three dummy variables from this data. The dummy variable IO intervention takes the value 1 if an IO militarily intervenes in a country. Similarly, a dummy variable democratic intervention is coded as 1 if a democratic state intervenes militarily. A country is coded as democratic if its Polity Score is $\geq 7$ at the time of the intervention. Finally, the dummy autocratic intervention takes the value of 1 if a state with a Polity Score $<7$ intervenes militarily in a country.

The literature on democratization and economic development alludes to a very strong relationship between GDP per capita and democratic institutions (e.g., Barro (1997)). Hence, I control for GDP per capita and population (Gleditsch, 2002) in the empirical model. Additionally, I control for the number of conflict parties that were active during a conflict. Finally, I control for the pre-conflict Polity score which should have a positive effect on both election timing and democratization.

\section{Results}

The first set of results relies on Cox proportional hazard models. The estimation results for post-conflict election timing can be found in Table 1. Results for the second set of models estimating the time until a country reaches a Polity score $\geq 6$ are presented in Table 3 . Model related summary statistics are provided at the bottom of each table. The coefficients show the impact of the explanatory variables on the hazard of an event taking place. Thus, positive coefficients imply that an independent variable increases the risk of election or democratization. The significance of each estimate is measured by two-tailed tests.

\footnotetext{
${ }^{5}$ The operational definition used by Kisangani and Pickering (2007) and Pearson and Baumann (1992) states that: "Military interventions are defined operationally in this collection as the movement of regular troops of forces (airborne, seaborne, shelling, etc) of one country inside another, in the context of some political issue or dispute" (Pearson and Baumann, 1992:1).
} 
5.1. Cox models: Hazard of post-conflict elections. In Model 1 (Table 1), I estimate a baseline model that excludes any of the theoretically implied interaction effects. Neither the government leader's ethnic group size nor any of the civil war outcome variables have a statistically significant effect on shifting the baseline hazard. However, IO interventions have a strong and positive effect on the underlying baseline hazard of post-war elections. This finding is very robust and significant across all models in Table 1 . In fact, out of the 14 conflicts with an IO intervention 11 eventually have post-war elections. Another relatively robust and expected finding is that countries with a high pre-conflict Polity score have earlier post-conflict elections than countries with a low pre-conflict Polity level.

An important assumption in the Cox model is that the explanatory variables shift the underlying baseline hazard proportional and that this proportionality is maintained over time. This implies that the relative hazard for any two combinations of $X \beta$ must be conform with the following proportional relationship in every time period $t$ (Keele, 2010):

$$
\frac{h_{0}(t) e^{X_{i} \beta}}{h_{0}(t) e^{X_{j} \beta}}=\frac{e^{X_{i} \beta}}{e^{X_{j} \beta}}
$$

The standard diagnostic to tests for nonproportional hazards analyze the Schoenfeld residuals. The most common diagnostic was developed by Grambsch and Therneau (1994) and utilizes the scaled Schoenfeld residuals to establish a global and a covariate specific test diagnostic. I follow Keele (2010) in the description of the covariate specific test statistic. First, let $s_{k}^{*}$ be the scaled Schoenfeld residuals for covariate $k$. Furthermore, define $g_{k}$ as $k$ 's time scale and $\bar{g}$ as the average time scale. The Grambsch and Therneau (1994) test statistic for detecting nonproportionality can then be written as:

$$
T_{k}=\frac{\left(\sum\left(g_{k}-\bar{g}\right) s_{k}^{*}\right)^{2}}{d I_{k} \sum\left(g_{k}-\bar{g}\right)^{2}}
$$

where $I_{k}$ is the information matrix elements for covariate $k$, and $d$ represents the event times. An intuitive interpretation of the test is that it measures the correlation between covariate specific residuals $s_{k}^{*}$ and event time $d$. One "problem" of this test statistic is that it not only detects nonproportionality but also more general issues of model misspecification (Keele, 2010). However, I will take advantage of this "weakness" of the Grambsch and Therneau (1994) test to conclude whether a model that includes the hypothesized interaction effects should be preferred over a model that excludes them. If the non-proportionality test gives us a positive result when the interaction 
TABle 1. Cox model estimates. Dependent variable: Time until first post-conflict election

\begin{tabular}{|c|c|c|c|c|}
\hline & Model 1 & Model 2 & Model 3 & Model 4 \\
\hline Government Leader's Ethnic Group Size & $\begin{array}{c}0.062 \\
(0.444)\end{array}$ & $\begin{array}{l}-0.504 \\
(0.711)\end{array}$ & $\begin{array}{c}-0.489 \\
(0.720)\end{array}$ & $\begin{array}{l}-0.864 \\
(0.935)\end{array}$ \\
\hline Government Victory & $\begin{array}{c}0.215 \\
(0.307)\end{array}$ & $\begin{array}{l}-0.059 \\
(0.463)\end{array}$ & $\begin{array}{l}-0.060 \\
(0.467)\end{array}$ & $\begin{array}{l}-0.076 \\
(0.503)\end{array}$ \\
\hline Rebel Victory & $\begin{array}{l}-0.031 \\
(0.526)\end{array}$ & $\begin{array}{l}-1.366 \\
(0.922)\end{array}$ & $\begin{array}{l}-1.341 \\
(0.924)\end{array}$ & $\begin{array}{l}-1.210 \\
(0.901)\end{array}$ \\
\hline Peace Agreement & $\begin{array}{c}0.228 \\
(0.475)\end{array}$ & $\begin{array}{c}0.156 \\
(0.524)\end{array}$ & $\begin{array}{c}0.250 \\
(0.522)\end{array}$ & $\begin{array}{c}0.363 \\
(0.554)\end{array}$ \\
\hline Government Interaction & & $\begin{array}{c}0.576 \\
(0.959)\end{array}$ & $\begin{array}{c}0.594 \\
(0.963)\end{array}$ & $\begin{array}{c}0.909 \\
(1.023)\end{array}$ \\
\hline Rebel Interaction & & $\begin{array}{c}3.932^{* *} \\
(1.558)\end{array}$ & $\begin{array}{c}3.907^{* *} \\
(1.577)\end{array}$ & $\begin{array}{l}3.765^{* *} \\
(1.550)\end{array}$ \\
\hline Agreement Interaction & & $\begin{array}{l}-0.011 \\
(1.051)\end{array}$ & $\begin{array}{l}-0.143 \\
(1.079)\end{array}$ & $\begin{array}{c}-0.649 \\
(1.197)\end{array}$ \\
\hline Democratic Intervention & $\begin{array}{c}0.112 \\
(0.340)\end{array}$ & $\begin{array}{c}0.167 \\
(0.365)\end{array}$ & $\begin{array}{c}0.193 \\
(0.363)\end{array}$ & $\begin{array}{c}0.273 \\
(0.380)\end{array}$ \\
\hline Non-Democratic Intervention & $\begin{array}{l}-0.243 \\
(0.436)\end{array}$ & $\begin{array}{l}-0.473 \\
(0.446)\end{array}$ & $\begin{array}{l}-0.443 \\
(0.446)\end{array}$ & $\begin{array}{l}-0.599 \\
(0.471)\end{array}$ \\
\hline IO Intervention & $\begin{array}{c}0.922^{* *} \\
(0.425)\end{array}$ & $\begin{array}{c}0.904^{* *} \\
(0.421)\end{array}$ & $\begin{array}{c}6.077^{* * *} \\
(1.248)\end{array}$ & $\begin{array}{c}6.571^{* * * *} \\
(1.432)\end{array}$ \\
\hline Pre-Conflict Polity Score & $\begin{array}{l}0.029^{*} \\
(0.017)\end{array}$ & $\begin{array}{c}0.038^{* *} \\
(0.017)\end{array}$ & $\begin{array}{c}0.037^{* *} \\
(0.017)\end{array}$ & $\begin{array}{l}0.036^{*} \\
(0.018)\end{array}$ \\
\hline Number of Rebel Organizations & $\begin{array}{l}-0.130 \\
(0.144)\end{array}$ & $\begin{array}{l}-0.166 \\
(0.145)\end{array}$ & $\begin{array}{l}-0.170 \\
(0.145)\end{array}$ & $\begin{array}{l}-0.185 \\
(0.152)\end{array}$ \\
\hline GDP per capita & $\begin{array}{c}0.116 \\
(0.111)\end{array}$ & $\begin{array}{c}0.132 \\
(0.112)\end{array}$ & $\begin{array}{c}0.121 \\
(0.115)\end{array}$ & $\begin{array}{c}0.077 \\
(0.191)\end{array}$ \\
\hline Population & $\begin{array}{c}0.115 \\
(0.088)\end{array}$ & $\begin{array}{c}0.095 \\
(0.094)\end{array}$ & $\begin{array}{c}0.099 \\
(0.095)\end{array}$ & $\begin{array}{c}0.053 \\
(0.106)\end{array}$ \\
\hline IO Intervention $\times \ln$ (Time) & & & $\begin{array}{c}-0.833^{* * *} \\
(0.205)\end{array}$ & $\begin{array}{c}-0.922^{* * *} * \\
(0.225)\end{array}$ \\
\hline America & & & & $\begin{array}{c}0.897 \\
(0.564)\end{array}$ \\
\hline Europe & & & & $\begin{array}{c}0.250 \\
(0.458)\end{array}$ \\
\hline Africa & & & & $\begin{array}{c}0.405 \\
(0.648)\end{array}$ \\
\hline Middle East & & & & $\begin{array}{c}0.167 \\
(0.504)\end{array}$ \\
\hline Observations & 140 & 140 & 140 & 140 \\
\hline Post-Conflict Elections & 96 & 96 & 96 & 96 \\
\hline Days at Risk & 124185 & 124185 & 124185 & 124185 \\
\hline & 24.35 & 26.48 & 65.36 & 69.81 \\
\hline Prob $>\chi^{2}$ & 0.001 & 0.001 & 0.001 & 0.001 \\
\hline Log-Likelihood & -370.8 & -367.4 & -366.5 & -365.0 \\
\hline
\end{tabular}

effects are excluded but a negative result if they are included, we can conclude that the model without the interaction effect was misspecified. This would give us considerable more certainty that the interaction model is the preferred one.

The first two columns in Table 2 display the Grambsch and Therneau (1994) nonproportionality test results for Model 1. $T_{k}$ refers to the "correlation" between the residuals and event times, while the p-value pertains to a $\chi^{2}$ test with 1 degree of freedom to whether $T_{k}$ is significantly different from 0 . Three variables have p-values $<.05$ indicating a violation of the proportionality 
assumption $^{6}$ : Rebel victory, peace agreement, and IO intervention. The standard approach would be to interact these variables with the log of time and include them into the estimated model (Box-Steffensmeier and Zorn, 2001). However, before using the standard approach, I first enter the hypothesized interaction effects and test whether Model 2 fairs better in the Grambsch and Therneau (1994) test.

Model 2 includes the theoretically implied interaction terms. In line with Hypothesis 1 the interaction effect of the rebel leaders' ethnic group size and rebel victory is positive and significant. This implies that victorious rebel leaders with large ethnic support are very likely to call for quick elections after the a conflict. However, this effect is not significant for successful incumbents and close to zero after peace agreements. But to see whether the inclusion of the interaction terms solves some of the problems of meeting the proportionality assumption in Model 1, we turn back to Table 2. Looking at the p-values for rebel victory and peace agreement, we can see that they now surpass the suggested critical value of 0.05 (Keele, 2010; Box-Steffensmeier and Zorn, 2001). In addition, the interaction terms pass this criterion as well. Furthermore, the test results for Model 2 suggest that rebel victory benefits the most from the inclusion of the interaction terms and that the global test statistic is substantively improved. Therefore, Model 2 provides substantial evidence that victorious rebel leaders with large ethnic support are more likely to initiate quick elections by: (1) revealing a positive and significant interaction between the post-war governments' ethnic group size and rebel victory and (2) improving the variable specific and global test statistic for nonproportionality, which suggests that Model 2 is the preferred specification over Model 1 that excluded the interaction terms.

The only variable that still reveals problems of nonproportionality in Model 2 is IO Intervention. Having explored the interaction terms between IO interventions and other variables in the model without improving the results of the Grambsch and Therneau (1994) test, I retreat to the standard approach of dealing with non-proportionality by including an interacted term with the log of time. Indeed, Model 3 suggests that in the case of IO interventions "actual" non-proportionality is the reason for misspecification in Model 1 and 2. First, the interacted term with $\ln$ (Time) is significant, second the variable-specific test statistic greatly improves, and finally the global test for Model 3 also fairs better than for Models 1 and 2. The estimated effects for all other variables in Model 3 are only marginally different from Model 2.

${ }^{6}$ As with other test statistic the threshold of 0.05 is relatively arbitrary. However, Box-Steffensmeier and Zorn (2001) and Keele (2010) argue this to be a reasonable cutoff point. 
TABLE 2. Grambsch and Therneau test for non-proportional hazards

\begin{tabular}{lcccccc}
\hline & \multicolumn{2}{c}{ Model 1} & \multicolumn{2}{c}{ Model 2} & \multicolumn{2}{c}{ Model 3} \\
& $T_{k}$ & p-value & $T_{k}$ & $\mathrm{p}$-value & $T_{k}$ & $\mathrm{p}$-value \\
\hline Government Leader's Ethnic Group Size & -0.06 & 0.42 & 0.11 & 0.17 & 0.11 & 0.15 \\
Government Victory & -0.10 & 0.28 & 0.08 & 0.43 & 0.08 & 0.41 \\
Rebel Victory & -0.18 & $\mathbf{0 . 0 1}$ & -0.03 & $\mathbf{0 . 6 4}$ & -0.02 & $\mathbf{0 . 7 2}$ \\
Peace Agreement & -0.23 & $\mathbf{0 . 0 1}$ & -0.13 & $\mathbf{0 . 1 6}$ & -0.11 & $\mathbf{0 . 2 4}$ \\
Democratic Intervention & 0.05 & 0.67 & -0.01 & 0.97 & 0.01 & 0.98 \\
Non-Democratic Intervention & -0.08 & 0.41 & -0.01 & 0.90 & -0.01 & 0.89 \\
IO Intervention & 0.20 & $\mathbf{0 . 0 1}$ & 0.21 & $\mathbf{0 . 0 1}$ & 0.10 & $\mathbf{0 . 5 8}$ \\
Pre-Conflict Polity Score & -0.04 & 0.67 & -0.15 & 0.13 & -0.15 & 0.13 \\
Number of Rebel Organizations & 0.01 & 0.98 & 0.05 & 0.56 & 0.05 & 0.57 \\
GDP per capita & -0.07 & 0.50 & -0.03 & 0.75 & -0.03 & 0.78 \\
Population & -0.13 & 0.16 & -0.14 & 0.09 & -0.14 & 0.07 \\
Government Interaction & & & -0.14 & 0.08 & -0.15 & 0.06 \\
Rebel Interaction & & & -0.02 & $\mathbf{0 . 8 1}$ & -0.02 & $\mathbf{0 . 7 5}$ \\
Agreement Interaction & & & -0.18 & $\mathbf{0 . 0 7}$ & -0.19 & $\mathbf{0 . 0 5}$ \\
IO Intervention $\times$ ln(Time) & & & & & 0.03 & $\mathbf{0 . 8 4}$ \\
\hline Global Test & & & & & & \\
\end{tabular}

Figure 3 plots the impact of the different conflict outcomes against the government leaders' ethnic group size to illustrate the interaction effects in Model 3. The plots reemphasize the described findings but additionally highlight that victorious rebel leaders are only significantly quicker to stage elections if their ethnic group consists of more than 50 percent of a country's population. This threshold fits very well with the theoretical argument as a majority of 50 percent is very likely to carry the challenger into office. While the interaction effect for government victories is also positive it is not significant at any value of the ethnic group size. This last finding is not in line with the theoretical implications and I return to this point when discussing the bivariate probit models.

\subsection{Cox models: Hazard of post-conflict democratization if elections occurred. The} second set of results focuses on the conditions under which post-conflict elections are succeeded by a democratic transition. As outlined above, I will define a country as democratic if its Polity score 
FigURE 3. Effect of civil war outcomes conditional on post-conflict government leaders' ethnic group size with 95\% Confidence Intervals (Model 3)
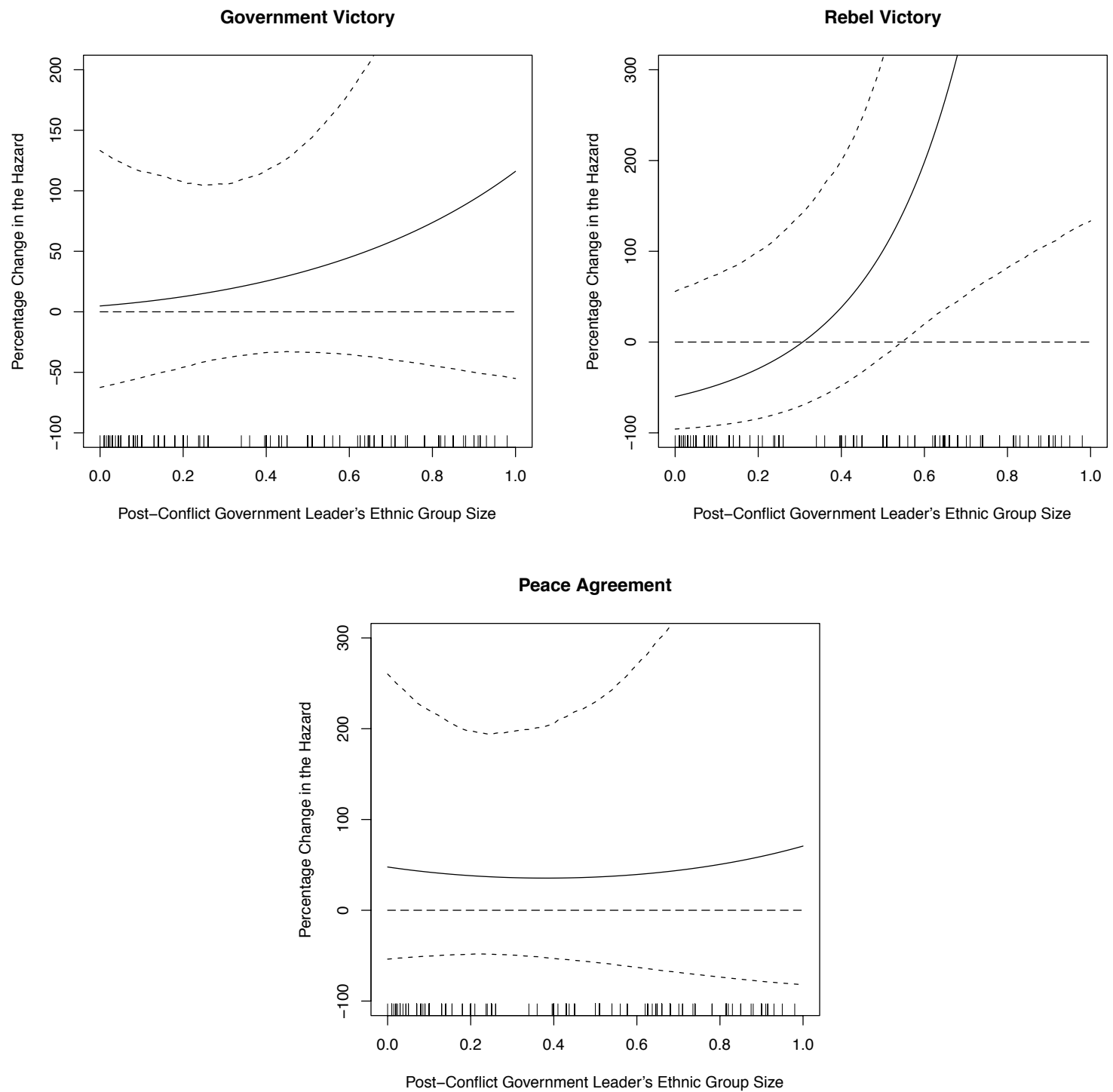

is $\geq 6^{7}$. Table 3 presents the Cox regression estimates with the dependent variable measuring the time between post-conflict elections and democratization. Before turning to the estimates, I want to reiterate that only in 49 out of 96 cases post-conflict elections lead up to democratization. This is an astonishing low number and highlights that post-war elections and post-war democratization are to some extent distinct processes. While post-conflict elections are a necessary condition for democratization, they are certainly not a sufficient one. In the following, I do not provide the previous extensive discussion of the proportionality diagnostics but the pattern is similar to the

\footnotetext{
${ }^{7}$ Slightly different cutoff points reveal similar results to the ones I present in this paper.
} 
one in Model 1-3. Rebel victories fail to pass the Grambsch and Therneau (1994) test and again this problem disappears once the interaction term is included. In contrast to Model 1-3, IO interventions meet the proportionality assumption but non-democratic interventions do not. Therefore, I include an interaction term of non-democratic interventions and $\ln$ (Time) in Models 5 and 6.

TABle 3. Cox model estimates. Dependent variable: Time between post-conflict elections and Polity score $\geq 6$

\begin{tabular}{|c|c|c|}
\hline & Model 5 & Model 6 \\
\hline Government Leader's Ethnic Group Size & $\begin{array}{c}0.574 \\
(0.474)\end{array}$ & $\begin{array}{c}0.412 \\
(0.617)\end{array}$ \\
\hline Government Victory & $\begin{array}{l}-0.102 \\
(0.399)\end{array}$ & $\begin{array}{c}0.095 \\
(0.851)\end{array}$ \\
\hline Rebel Victory & $\begin{array}{c}0.680 \\
(0.634)\end{array}$ & $\begin{array}{l}-0.304 \\
(0.961)\end{array}$ \\
\hline Peace Agreement & $\begin{array}{c}0.922 \\
(0.584)\end{array}$ & $\begin{array}{c}0.958 \\
(0.733)\end{array}$ \\
\hline Government Interaction & & $\begin{array}{c}-0.275 \\
(1.294)\end{array}$ \\
\hline Rebel Interaction & & $\begin{array}{l}2.585^{*} \\
(1.374)\end{array}$ \\
\hline Agreement Interaction & & $\begin{array}{l}-0.458 \\
(1.213)\end{array}$ \\
\hline Democratic Intervention & $\begin{array}{c}1.029^{* *} \\
(0.442)\end{array}$ & $\begin{array}{l}1.000^{* *} \\
(0.458)\end{array}$ \\
\hline Non-Democratic Intervention & $\begin{array}{l}1.374^{*} \\
(0.823)\end{array}$ & $\begin{array}{c}0.980 \\
(0.916)\end{array}$ \\
\hline IO Intervention & $\begin{array}{c}1.206^{* *} \\
(0.564)\end{array}$ & $\begin{array}{c}1.394^{* *} \\
(0.640)\end{array}$ \\
\hline Pre-Conflict Polity Score & $\begin{array}{c}0.197^{* * *} \\
(0.031)\end{array}$ & $\begin{array}{c}0.217^{* * *} \\
(0.037)\end{array}$ \\
\hline Number of Rebel Organizations & $\begin{array}{c}0.148 \\
(0.308)\end{array}$ & $\begin{array}{c}0.081 \\
(0.328)\end{array}$ \\
\hline GDP per capita & $\begin{array}{c}0.057 \\
(0.222)\end{array}$ & $\begin{array}{l}-0.020 \\
(0.227)\end{array}$ \\
\hline Population & $\begin{array}{c}0.145 \\
(0.125)\end{array}$ & $\begin{array}{c}0.105 \\
(0.125)\end{array}$ \\
\hline Non-Democratic Intervention $\times \ln ($ Time $)$ & $\begin{array}{c}-0.578^{* * *} \\
(0.140)\end{array}$ & $\begin{array}{c}-0.558^{* * *} \\
(0.147)\end{array}$ \\
\hline Observations & 96 & 96 \\
\hline Democratization & 49 & 49 \\
\hline Days at Risk & 177231 & 177231 \\
\hline$\chi$ & 109.5 & 112.9 \\
\hline Prob $>\chi^{2}$ & 0.001 & 0.001 \\
\hline Log-Likelihood & -161.2 & -159.8 \\
\hline
\end{tabular}

Turning to the control variables in Model 5 and 6 reveals that IO interventions are not only a good predictor for post-conflict elections but also for post-conflict democratization. Similarly and not surprisingly is the pre-conflict Polity score positively and significantly related to a quick postwar democratization. Different to the previous models, democratic interventions now significantly increase the "risk" of democratization. In addition, non-democratic interventions also seem to 
FigURE 4. Effect of rebel victory conditional on post-conflict government leaders' ethnic group size with 95\% Confidence Intervals (Model 6)

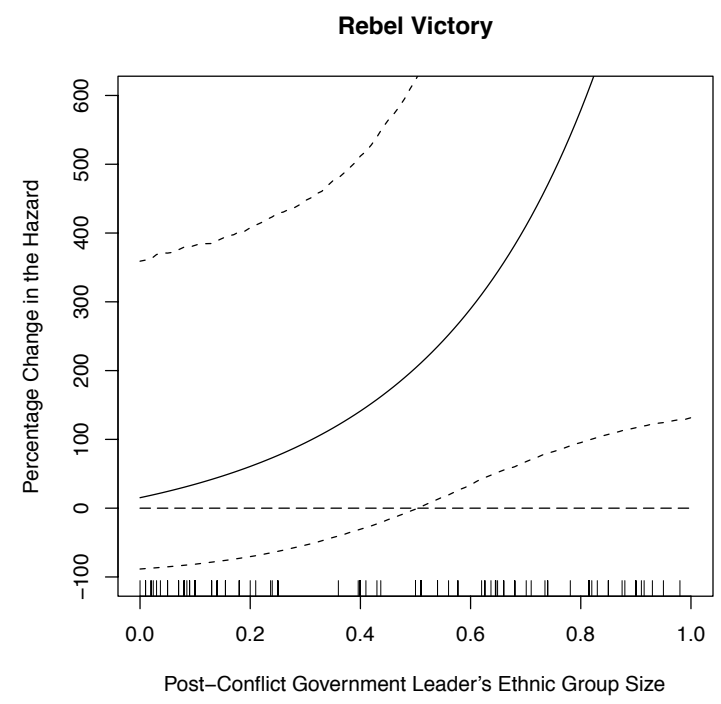

decrease the time until first post-conflict elections but this effect is offset by the negative effect they have if conflicts last longer.

When introducing the interaction terms in Model 6, we arrive at similar results as in Models 2-4. Incumbent and rebel victories are associated with post-war democratization if the post-war government leader comes from large ethnic groups. While this effect is significant for rebel victories, this is not the case when incumbents successfully defend their office. Figure 4 provides a graphical interpretation of the interaction effect for rebel victories. Similar to the post-conflict election results, the effect of the post-war governments' ethnic group size becomes significant if the ethnic represents more than 50 percent of the population. This finding is in line with Hypothesis 3 that successful challengers with large ethnic support are not only likely to call for quick election but also push for democratization measures. The negative but non-significant interaction between government victories and the post-war government leaders' ethnic group size provides support for Hypothesis 2 that successful incumbents are unlikely to implement democratic institutions.

Summarizing the results, I find strong support for the hypotheses that successful rebel leaders from large ethnic groups use elections and democratization to consolidate their power (Hypothesis 1 and 3). Based on the Cox results, successful incumbents seem not to utilize elections to consolidate their power but in line with Hypothesis 2 avoid democratization. 
5.3. Bivariate Probit results. While the results from the Cox models provide important findings that support the main hypotheses of this paper, they do not capture the interdependency between the decision to stage elections and/or democratize. However, it is theoretically sensitive to assume that the decision to call for elections will depend on the intention to democratize. But similarly, the decision to stage elections can also increase the demand for democratization even if elections were originally suppose to simply consolidate and legitimate one's power. This implies that the post-conflict government's decision to stage elections and/or democratize should explicitly be modeled as two distinct but dependent processes. However, implementing such an approach in a duration framework is problematic since interdependent duration models are rare in political science (Hays and Kachi, 2009; Hays, 2009). For example, Quiroz Flores (2008) estimates the tenure of chief executive officers and the median duration of their ministers as interdependent durations using a seemingly unrelated regression (SUR) approach. Darmofal (2009) uses a spatial-error approach to estimate issue position taking on NAFTA in the U.S. Congress. However, a problem of adapting these estimation approaches it that the mentioned estimators do not allow for rightcensored observations. This would be unproblematic if only a few observation were affected which could be dropped in the analysis. Yet, especially in the case of post-conflict democratization $2 / 3$ of the cases never experience the event. Therefore, I implement a simpler estimation approach to address the possible endogeneity between post-conflict elections and democratization. I do so by estimating a series of seemingly unrelated bivariate probit models which allow for two processes with dichotomous dependent variables where the error terms are correlated. One way of addressing the endogeneity of these processes is to include the outcome variable of the second equation on the right hand side of the first one. More formally this recursive multiple equation biprobit model with endogenous dummy regressors (EDR) can be expressed as (Maddala, 1983):

$$
\begin{aligned}
& y_{1 i}^{*}=\delta_{1 i} y_{2 i}+X \beta_{1 i}+\epsilon_{1 i} \\
& y_{2 i}^{*}=\quad X \beta_{2 i}+\epsilon_{2 i} \\
& y_{1 i}=\left\{\begin{array}{ll}
1 & \text { if } y_{1 i}^{*}>0 \\
0 & \text { otherwise }
\end{array} \quad y_{2 i}= \begin{cases}1 & \text { if } y_{2 i}^{*}>0 \\
0 & \text { otherwise }\end{cases} \right.
\end{aligned}
$$

Therefore, I create two outcome variables which correspond to the failure indicators of the first two models. Thus, the first dependent variable indicates whether post-conflict elections took place 
and the second dependent variable measures whether post-conflict democratization was achieved. Models 7 and 8 provide the results for two separate probit models to establish a baseline against the bivariate probit models. Overall, the results are in line with the Cox regression results. In regard to the main explanatory variables the interaction effect of rebel victory and the post-conflict government leader's ethnic group size is positive and significant in both models. Similar to the Cox results, the interaction effect for government victories is positive but not significant. IO intervention predicts too many post-conflict elections perfectly and is therefore dropped from Model 7, but it is positively and significantly related to post-war democratization in Model 8. A higher GDP per capita now increases the probability of post-conflict elections significantly, while democratic and non-democratic interventions have opposite effects on post-war democratization. As in the previous models pre-conflict Polity scores are a good predictor for both post-conflict elections and democratization. While these results are only an intermediate step, they additionally provide evidence that the findings of the Cox models are robust to alternative estimation strategies.

Turning to the bivariate probit estimates in Table 4, Model 9 provides a SUR estimation but without modeling the endogeneity between post-conflict elections and democratization. The results are extremely consistent with the two probit models but the significant $\rho$ parameter indicates that the error terms of the two equations are highly correlated. Model 10 accounts for the endogeneity of these processes by including the post-conflict democratization dummy into the post-conflict election equation. One should note that in contrast to linear simultaneous equations with only continuous endogenous variables, the recursive multiple equation probit model with endogenous dummy regressors does not need an exclusion restriction for the exogenous variables (Wilde, 2000). Reason for concern however is that the $\rho$ parameter in Model 10 approximates -1, which could imply problems of convergence and hence biased estimates. Therefore, I restricted the model at $\rho=-0.25 ;-0.5 ;-0.75$ to see whether the estimated results greatly differ. However, Model 10 with $\rho=-$ 0.99 results in comparatively conservative estimates and I present those results. When assessing the goodness of fit we can see that the EDR model is much better at correctly predicting post-conflict elections. Figure 5 compares how well Models 7, 9, and 10 can distinguish between cases that do and do not hold post-conflict elections. While the SUR (Model 9) does slightly better than the standard probit model (Model 7), the EDR (Model 10) is not unexpectedly the best fitting model. In regard to the prediction of democratic post-conflict orders all models (Model 8-10) perform very 
TABLE 4. Probit and bivariate probit estimates

\begin{tabular}{|c|c|c|c|c|c|c|}
\hline \multirow[b]{2}{*}{ Democratization } & \multirow[t]{2}{*}{$\begin{array}{c}\text { Model } 7 \\
\text { Probit }\end{array}$} & \multirow[t]{2}{*}{$\begin{array}{c}\text { Model } 8 \\
\text { Probit }\end{array}$} & \multicolumn{2}{|c|}{$\begin{array}{l}\text { Model } 9 \\
\text { SUR }\end{array}$} & \multicolumn{2}{|c|}{$\begin{array}{l}\text { Model } 10 \\
\text { EDR }\end{array}$} \\
\hline & & & & & $\begin{array}{c}2.948^{* * *} \\
(0.337)\end{array}$ & \\
\hline Government Leader's ethnic group size & $\begin{array}{l}-0.309 \\
(0.711)\end{array}$ & $\begin{array}{c}0.863 \\
(0.747)\end{array}$ & $\begin{array}{c}-0.322 \\
(0.761)\end{array}$ & $\begin{array}{c}0.784 \\
(0.704)\end{array}$ & $\begin{array}{l}-0.852 \\
(0.624)\end{array}$ & $\begin{array}{c}0.981 \\
(0.664)\end{array}$ \\
\hline Government Victory & $\begin{array}{c}0.194 \\
(0.635)\end{array}$ & $\begin{array}{c}0.580 \\
(0.672)\end{array}$ & $\begin{array}{c}0.208 \\
(0.643)\end{array}$ & $\begin{array}{c}0.501 \\
(0.659)\end{array}$ & $\begin{array}{c}-0.188 \\
(0.484)\end{array}$ & $\begin{array}{c}0.773 \\
(0.510)\end{array}$ \\
\hline Rebel Victory & $\begin{array}{l}-0.500 \\
(0.828)\end{array}$ & $\begin{array}{l}-0.661 \\
(0.751)\end{array}$ & $\begin{array}{l}-0.527 \\
(0.861)\end{array}$ & $\begin{array}{l}-0.618 \\
(0.723)\end{array}$ & $\begin{array}{l}-0.271 \\
(0.592)\end{array}$ & $\begin{array}{l}-0.632 \\
(0.619)\end{array}$ \\
\hline Peace Agreement & $\begin{array}{l}1.019 \\
(0.986)\end{array}$ & $\begin{array}{c}0.283 \\
(0.647)\end{array}$ & $\begin{array}{c}0.892 \\
(0.737)\end{array}$ & $\begin{array}{c}0.353 \\
(0.665)\end{array}$ & $\begin{array}{c}0.869 \\
(0.645)\end{array}$ & $\begin{array}{c}0.351 \\
(0.604)\end{array}$ \\
\hline Government Interaction & $\begin{array}{l}1.766 \\
(1.192)\end{array}$ & $\begin{array}{l}-0.685 \\
(1.102)\end{array}$ & $\begin{array}{l}1.820 \\
(1.232)\end{array}$ & $\begin{array}{l}-0.505 \\
(1.093)\end{array}$ & $\begin{array}{l}2.061^{* *} \\
(1.006)\end{array}$ & $\begin{array}{l}-0.979 \\
(0.908)\end{array}$ \\
\hline Rebel Interaction & $\begin{array}{l}4.048^{* *} \\
(1.988)\end{array}$ & $\begin{array}{c}2.958^{* *} \\
(1.384)\end{array}$ & $\begin{array}{l}4.478^{* *} \\
(2.174)\end{array}$ & $\begin{array}{l}3.018^{* *} \\
(1.360)\end{array}$ & $\begin{array}{l}3.016^{* *} \\
(1.527)\end{array}$ & $\begin{array}{l}2.784^{* *} \\
(1.207)\end{array}$ \\
\hline Agreement Interaction & $\begin{array}{l}-1.737 \\
(2.136)\end{array}$ & $\begin{array}{c}0.223 \\
(1.563)\end{array}$ & $\begin{array}{l}-1.625 \\
(1.670)\end{array}$ & $\begin{array}{c}0.542 \\
(1.609)\end{array}$ & $\begin{array}{l}-2.139 \\
(1.465)\end{array}$ & $\begin{array}{c}-0.168 \\
(1.449)\end{array}$ \\
\hline GDP per capita & $\begin{array}{l}0.290^{*} \\
(0.163)\end{array}$ & $\begin{array}{l}-0.088 \\
(0.168)\end{array}$ & $\begin{array}{l}0.307^{*} \\
(0.162)\end{array}$ & $\begin{array}{l}-0.165 \\
(0.173)\end{array}$ & $\begin{array}{c}0.353^{* *} \\
(0.142)\end{array}$ & $\begin{array}{l}-0.009 \\
(0.153)\end{array}$ \\
\hline Population & $\begin{array}{l}-0.144 \\
(0.140)\end{array}$ & $\begin{array}{c}-0.084 \\
(0.118)\end{array}$ & $\begin{array}{l}-0.148 \\
(0.132)\end{array}$ & $\begin{array}{c}-0.076 \\
(0.120)\end{array}$ & $\begin{array}{l}-0.133 \\
(0.097)\end{array}$ & $\begin{array}{l}-0.081 \\
(0.100)\end{array}$ \\
\hline Pre-Conflict Polity Score & $\begin{array}{c}0.065^{* *} \\
(0.027)\end{array}$ & $\begin{array}{c}0.172^{* * * *} \\
(0.026)\end{array}$ & $\begin{array}{c}0.066^{* *} \\
(0.027)\end{array}$ & $\begin{array}{c}0.175^{* * *} \\
(0.029)\end{array}$ & $\begin{array}{c}-0.076^{* * *} \\
(0.025)\end{array}$ & $\begin{array}{c}0.165^{* * *} \\
(0.023)\end{array}$ \\
\hline Democratic Intervention & $\begin{array}{c}0.294 \\
(0.474)\end{array}$ & $\begin{array}{c}0.930^{*} \\
(0.538)\end{array}$ & $\begin{array}{c}0.271 \\
(0.494)\end{array}$ & $\begin{array}{l}1.002^{*} \\
(0.565)\end{array}$ & $\begin{array}{l}-0.249 \\
(0.446)\end{array}$ & $\begin{array}{l}0.781^{*} \\
(0.443)\end{array}$ \\
\hline Non-Democratic Intervention & $\begin{array}{l}0.340 \\
(0.532)\end{array}$ & $\begin{array}{c}-1.537^{*} \\
(0.785)\end{array}$ & $\begin{array}{c}0.334 \\
(0.573)\end{array}$ & $\begin{array}{c}-1.663^{*} \\
(0.854)\end{array}$ & $\begin{array}{l}0.992^{*} \\
(0.511)\end{array}$ & $\begin{array}{c}-1.235^{* *} \\
(0.570)\end{array}$ \\
\hline IO Intervention & & $\begin{array}{c}1.761^{* * *} \\
(0.567)\end{array}$ & $\begin{array}{c}7.845^{* * *} \\
(0.427)\end{array}$ & $\begin{array}{c}1.683^{* * *} \\
(0.543)\end{array}$ & $\begin{array}{c}6.277^{* * *} * \\
(0.766)\end{array}$ & $\begin{array}{c}1.759^{* * *} \\
(0.587)\end{array}$ \\
\hline Constant & $\begin{array}{l}-0.408 \\
(2.010)\end{array}$ & $\begin{array}{c}0.746 \\
(1.867)\end{array}$ & $\begin{array}{c}-0.491 \\
(1.986)\end{array}$ & $\begin{array}{c}1.306 \\
(2.006)\end{array}$ & $\begin{array}{c}-1.878 \\
(1.464)\end{array}$ & $\begin{array}{c}0.038 \\
(1.522)\end{array}$ \\
\hline$\rho$ & & & 0.827 & $7 * * *$ & -0.990 & $* * *$ \\
\hline Observations & 132 & 140 & 14 & & 14 & \\
\hline$\chi$ & 37.69 & 63.98 & 30 & 38 & $26:$ & \\
\hline Prob $>\chi^{2}$ & 0.001 & 0.001 & 0.0 & & 0.0 & \\
\hline Log-Likelihood & -68.51 & -57.46 & -11 & 5.5 & -113 & \\
\hline
\end{tabular}

well. Figure 6 demonstrates that the EDR model does slightly better than the other two models, but the difference is not substantial.

The results of the Cox models suggested that the model fit improved when including the interaction effects. The same pattern arises when looking at the bottom of Figures 5 and 6 . The bottom panels show the predicted probabilities for all models excluding the interaction terms ${ }^{8}$. Comparing the top and bottom plots, it becomes obvious that the inclusion of interaction terms improves the model-fit especially for the prediction of post-conflict democratization (Figure 6). However, it also shows that for post-conflict elections the EDR model vastly improves in model it when the interaction terms are included (Figure 5).

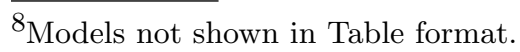


FigURE 5. Box plotted predicted probabilities for the actual events (no post-conflict election vs. post-conflict elections) in Models 7, 9, and 10. For comparison, box plotted predicted probabilities for models without interaction effects at the bottom.
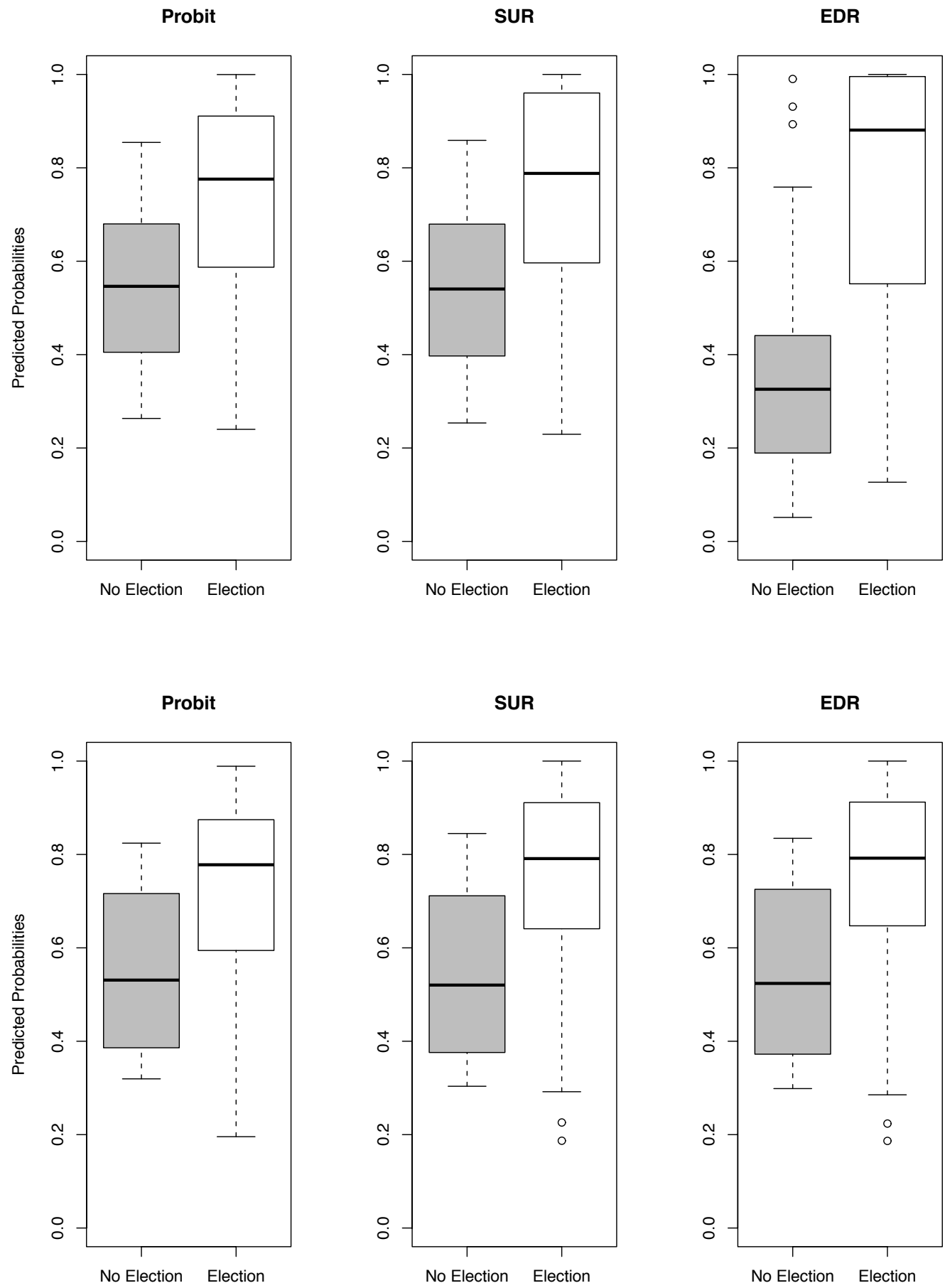
FiguRE 6. Box plotted predicted probabilities for the actual events (no post-conflict democracy vs. post-conflict democracy) in Models 8, 9, and 10. For comparison, box plotted predicted probabilities for models without interaction effects at the bottom.
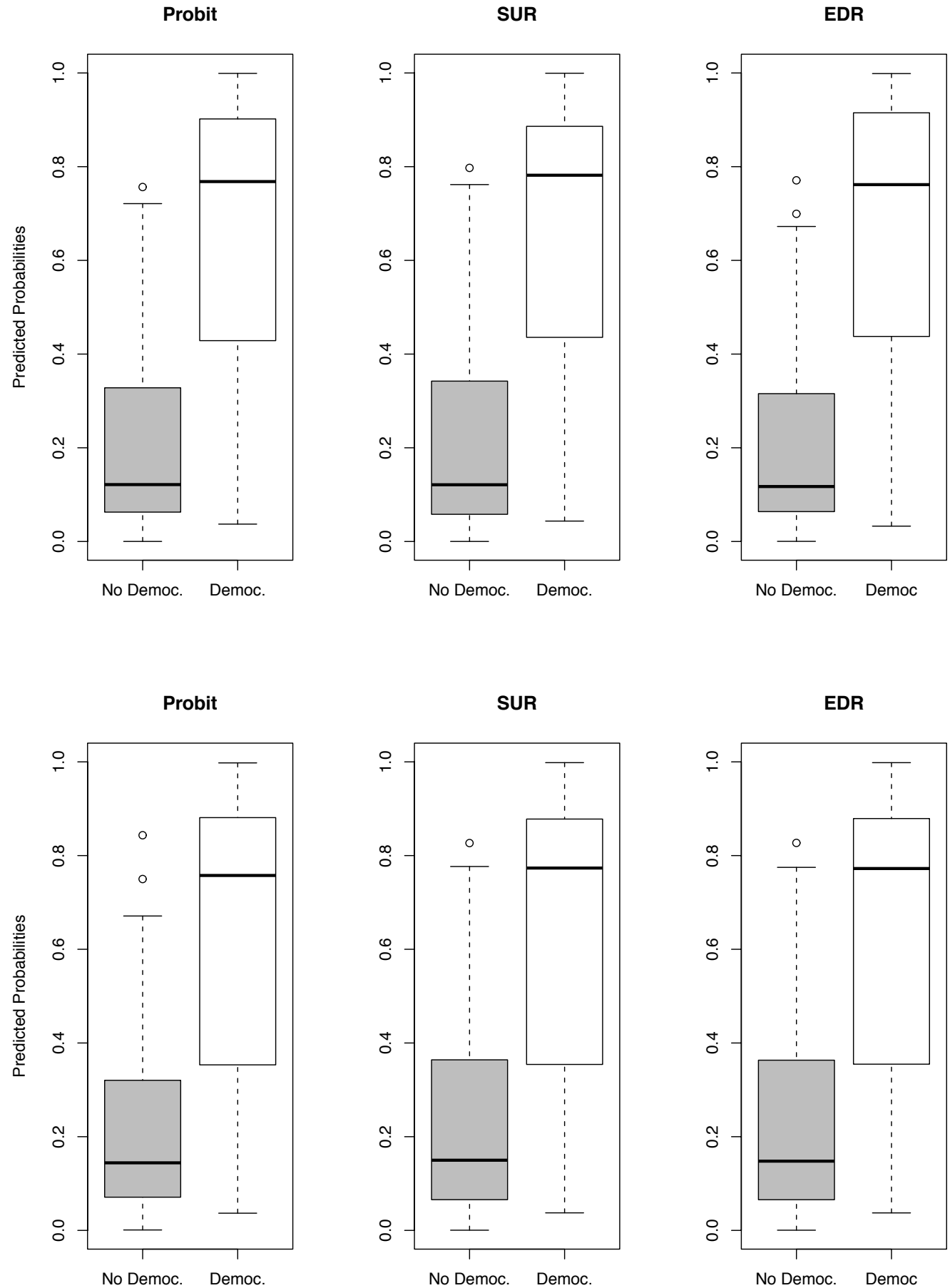
Turning to the estimates of the control variables in the EDR model (Model 10), slight changes to the SUR model (Model 9) can be observed. While GDP per capita, population size, democratic interventions, and IO intervention provide similar results, I shortly highlight some changes in the other control variables. The positive effect of non-democratic interventions on the probability of post-conflict elections is now significant and the pre-conflict Polity score estimate is now slightly negative and significant. The negative impact of the pre-conflict Polity score results from the fact that the second equation already accounts for the strong positive effect of the pre-conflict score. The remaining negative covariation results from pre-conflict democracies that do not stay democratic after the conflict and do not have any post-conflict elections.

In line with the theoretical considerations, Model 10 confirms that the decision to democratize highly impacts on the decision to stage elections. In contrast to the previous models, the government victory interaction term slightly increases and becomes significant in the post-election equation. To see why the interaction term becomes significant consider Figure 7 . The panels in Figure 7 display the predicted probabilities for post-conflict elections plotted against the post-conflict government leader's ethnic group size if the incumbent government stays in power. The connected red crosses are the actual post-conflict elections while the connected blue circles are the observation that do not experience any post-conflict elections. In the optimal case all red crosses would be at the top of the plot and blue circles would be at the bottom. This would imply that the model performs very good at differentiating post-conflict elections from cases without elections across all values of the government leader's ethnic group size. The left panel shows the predicted probabilities for Model 7. The simple probit model does a very good job at predicting post-conflict elections if the post-conflict government leader comes from a large ethnic group and the incumbent stays in power. However at lower levels of the government leaders ethnic group size Model 7 is not very good at differentiating between positive and negative cases. Cases without post-conflict elections have a quite high predicted probability and overlap with positive cases. This leads to a very high falsepositive rate in Model 7 if the incumbent succeeds. When considering the "standard" cutoff point of 0.5 , the false-positive rate is 100 percent (6 of 6 ). Using a more appropriate model related cutoff point by using the mean predicted probability, the false-positive rate is still at 50 percent. The same pattern arises when looking at the SUR (Model 9) plot in the middle of Figure 7. However, when looking at the very left EDR panel (Model 10) a different picture emerges. This model is much better at differentiating positive (red) from negative (blue) cases. First using the "standard" 
threshold of .5, the false-positive rate drops from 100 to 50 percent (3 of 6). Using the model's mean predicted probability as a cutoff point, leaves the false-positive at 33 percent ( 2 of 6 ). It is true that this improvement in the false-positive rate comes at the cost of a slightly worse false-negative rate. With the "standard" threshold the false-negative rate increases to 11.5 percent (Probit: $3.8 \%$; SUR: 3.8\%). Using the model related threshold, the false-negative rate increases to 30.8 percent (Probit: 15.4\%; SUR: 19.2\%). This implies that the significant interaction effect is attributable to the EDR model's improvement in the false-positive rate even though this comes at the cost of a fairly worse false-negative rate.

The general findings of the EDR model are in line with Hypothesis 1 which suggested that both successful incumbents and challengers from large ethnic groups have incentives to stage post-conflict elections and thereby consolidate their power. This implies that once we account for the endogeneity of post-conflict elections and democratization, we find support for for Hypothesis 1. Another important finding is that the interaction effects of rebel victories and the post-conflict leader's ethnic group size is slightly smaller in Model 10. This suggests that we slightly overestimated this effect in the previous models. The results in the democratization equation are consistent with the previous models even though the rebel victory interaction effect is also slightly smaller.

\section{Conclusion}

This paper is motivated by the fact that many countries experience elections after an armed conflict even though this is rarely succeeded by the implementation of fully democratic institutions. The paper provided theoretical arguments and statistical evidence that the post-conflict government leader's ethnic group size is an important factor in explaining election timing and democratization after an armed conflict. Victorious challengers and incumbents that belong to large ethnic groups are more likely to stage quick elections after an armed conflict. These post-conflict leaders can utilize elections to gain domestic reputation and international support which stabilizes their political position. The Cox model estimates showed that this finding primarily pertains to victorious rebel leaders. However, once I modeled the endogeneity of the decision to call for elections and the decision to implement democratic institutions, also victorious incumbents from large ethnic groups are more likely to utilize elections.

The paper also pointed out that only half of the post-conflict elections are actually succeeded by democratization. The theoretical section highlighted that post-conflict leaders should generally hinder democratization because democratic institutions increase the risk of government turnover. 
FigURE 7. Predicted probabilities of post-conflict elections for government victories in respect to the government leader's ethnic group size (Models 7, 9, and 10). Blue circles represent cases without post-conflict elections. Red crosses pertain to cases with post-conflict elections.

Probit

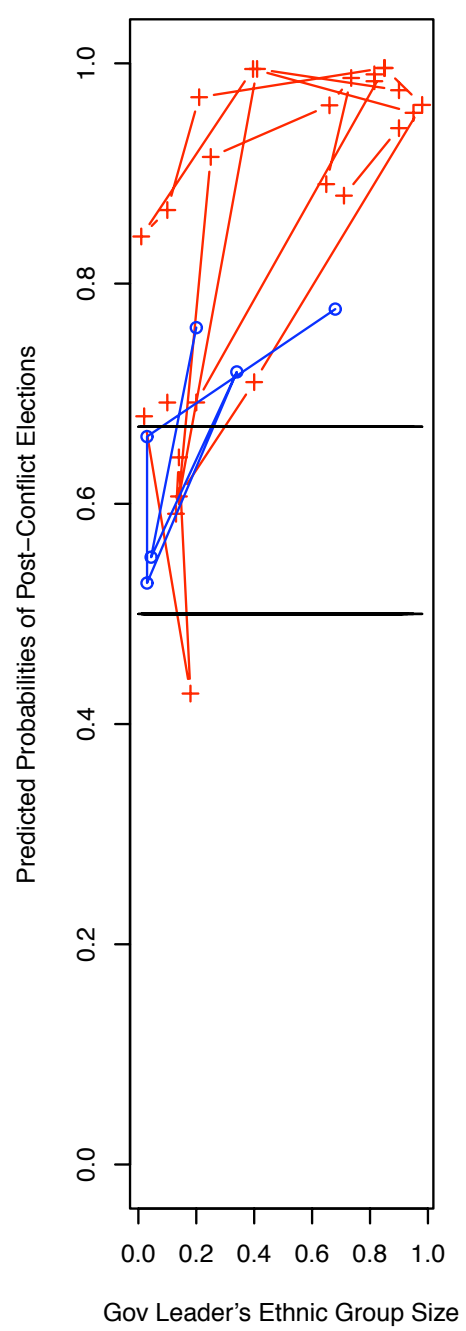

SUR

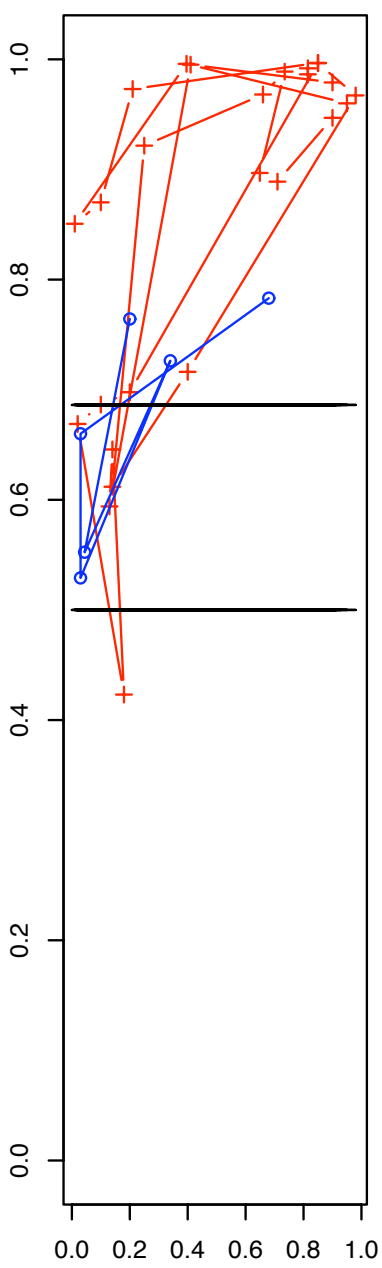

Gov Leader's Ethnic Group Size
EDR

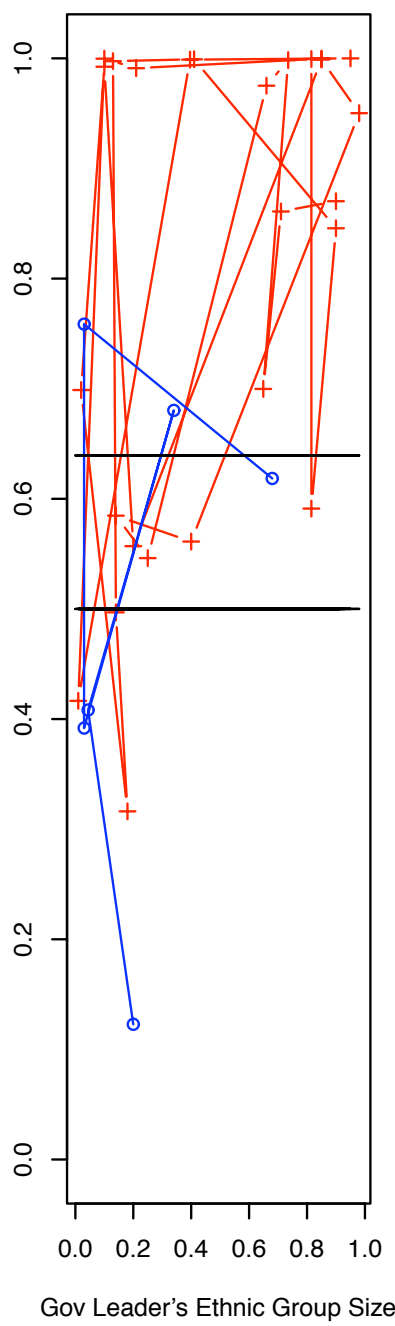

However, I argued that successful incumbents and challengers face different constraints by their supporters when deciding over post-conflict institutions. The supporters of the former rebel leader are more likely to belong the the politically and economically excluded non-elites. The non-elites prefer democratic institutions because they guarantee more restributional government policies. If the challenger's supporters additionally belong to a large ethnic group they will pressure their leader to install democratic institutions. Indeed, I can show across all model that post-conflict democratization becomes more likely if the the rebels win and the new leader belongs to a large ethnic group. 
Overall, the empirical results support the implications of the theoretical model. Nonetheless there are important limitations of this study. Most importantly, it would be preferable to estimate the endogeneity of election timing and democratization in a duration-duration framework. In this study, I retreated to a recursive multiple equation probit model with endogenous dummy regressors (EDR) because the data includes a large number of right-censored observations. Further research would be necessary to implement a duration-duration model that allows for right-censoring. Another limitation of this study is that it very much focuses on rebel or government victories. Further research could explore the institutional setup after peace agreements by identifying the ethnic group size of all political leaders at the bargaining table. For example, one could then analyze whether post-conflict institutions depends on the political leader with the smallest ethnic groups size who may veto any democratization efforts.

In sum, this paper demonstrates that post-conflict government leaders condition their postconflict institutional choices on the size of their ethnic group. This finding is especially pronounced fore victorious rebel leaders that take over government office. The finding support the idea that political leaders from large ethnic groups can utilize their support to marginalize political opponents. The paper also highlights that it is important to open up the black box of political leaders' characteristics to explain post-conflict dynamics. Therefore, this paper contributes to the growing literature that stresses that organizational (Humphreys and Weinstein, 2006), power-related (Cunningham, Gleditsch and Salehyan, 2009), and geographic attributes (Cederman, Buhaug and Rød, 2009; Weidmann, 2009) of political organizations matter when explaining conflict dynamics.

\section{REFERENCES}

Acemoglu, D. and James A. Robinson. 2006. Economic origins of dictatorship and democracy. Cambridge: Cambridge University Press.

Armey, Laura E and Robert M McNab. 2015. "Democratization and civil war." Applied Economics 47(18):1863-1882.

Barro, Robert J. 1997. Determinants of economic growth: A cross-country empirical study. Cambridge: MIT Press.

Besley, Timothy. 1995. "Property rights and investment incentives: Theory and evidence from Ghana." Journal of Political Economy 103(5):903-937.

Boix, Charles. 2003. Democracy and redistribution. Cambridge: Cambridge University Press. 
Box-Steffensmeier, Janet M. and Christopher Zorn. 2001. "Duration models and proportional hazards in political science." American Journal of Political Science 45(4):972-988.

Bratton, Michael and Nicolas van de Walle. 1997. Democratic experiments in africa: Regime transitions in comparative perspective. Cambridge: Cambridge University Press.

Bueno de Mesquita, Bruce, J.D. Morrow, R.M. Siverson and A. Smith. 2003. The logic of political survival. Cambidge: MIT Press.

Cederman, Lars-Erik and Luc Girardin. 2007. "Beyond fractionalization: Mapping ethnicity onto nationalist insurgencies." American Political Science Review 101(1):173-185.

Cederman, Lars, Halvard Buhaug and Jan Ketil Rød. 2009. "Ethno-nationalist dyads and civil war: A GIS-based analysis." Journal of Conflict Resolution 53(4):496-525.

Colaresi, Michael. 2014. "With friends like these, who needs democracy? The effect of transnational support from rivals on post-conflict democratization." journal of Peace Research 51(1):65-79.

Collier, Paul. 2009. Wars, guns and votes. London: Bodley Head.

Cox, Gary W. 1997. Making votes count. Strategic coordination in the world's electoral systems. Cambridge: Cambridge University Press.

Cunningham, David, Kristian Skrede Gleditsch and Idean Salehyan. 2009. "It takes two: A dyadic analysis of civil war duration and outcome." Journal of Conflict Resolution 53(4):570-597.

Darmofal, David. 2009. "Bayesian spatial survival models for political event processes." American Journal of Political Science 53(1):241-257.

Doyle, Michael W. and Nicholas Sambanis. 2000. "International peacebuilding: A theoretical and quantitative analysis." American Political Science Review 94(4):779-801.

Dresden, Jennifer Raymond. 2017. "From combatants to candidates: Electoral competition and the legacy of armed conflict." Conflict management and peace science 34(3):240-263.

Durant, T Clark and Michael Weintraub. 2014. "How to make democracy self-enforcing after civil war: Enabling credible yet adaptable elite pacts." Conflict Management and Peace Science $31(5): 521-540$.

Epstein, David L., Robert Bates, Jack Goldstone, Ida Kristensen and Sharyn O'Halloran. 2006. "Democratic transitions." American Journal of Political Science 50(3):551-569.

Fearon, James D. 2003. "Ethnic and cultural diversity by country." Journal of Economic Growth $8(2): 195-222$. 
Fearon, James D., Kimuli Kasara and David D. Laitin. 2007. "Ethnic minority rule and civil war onset." American Political Science Review 101(1):187-193.

Fortna, Virginia Page. 2004. "Does peacekeeping keep peace? International intervention and the duration of peace after civil war." International Studies Quarterly 48:269-292.

Fortna, Virginia Page and Reyko Huang. 2012. "Democratization after civil war: A brush-clearing exercise." International Studies Quarterly 56(4):801-808.

Geddes, Barbara. 2007. What causes democratization? In The Oxford handbook of comparative politics, ed. Charles Boix and Susan Carol Strokes. Oxford: Oxford University Press pp. 317-339.

Gleditsch, Kristian Skrede. 2002. "Expanded trade and GDP data." Journal of Conflict Resolution 46(05):712-24.

Gleditsch, Kristian Skrede. 2007. "Transnational dimensions of civil war." Journal of Peace Research 44(3):293-309.

Goemans, H.E., Kristian Skrede Gleditsch and Giacomo Chiozza. 2009. "Introducing Archigos: A data set of political leaders." Journal of Peace Research 46(2):269-283.

Grambsch, Patricia M. and Terry M. Therneau. 1994. "Proportional hazards tests and diagnostics based on weighted residuals." Biometrika 81(3):515-526.

Greif, Avner and David D. Laitin. 2004. "A theory of endogenous institutional change." American Political Science Review 98(04):633-652.

Gurses, Mehmet and Mason T. David. 2008. "Democracy Out of Anarchy: The Prospects for Post-Civil-War Democracy." Social Science Quarterly 89(2):315-336.

Hartzell, Caroline A and Matthew Hoddie. 2015. "The Art of the Possible: Power Sharing and PostCivil War Democracy." World Politics 67(1):37-71.

Hartzell, Caroline and Matthew Hoddie. 2003. "Institutionalizing peace: Power sharing and postcivil war conflict management." American Journal of Political Science 47(2):318-332.

Hays, Jude C. 2009. Bucking the system: Using simulation methods to estimate and analyze systems of equations with qualitative and limited dependent variables. St. Louis: St. Louis Area methods Meeting (SLAMM).

Hays, Jude C. and Aya Kachi. 2009. Interdependent duration models in political science. American Political Science Association Annual Meeting, September 3-6: Toronto, Canada.

Hegre, Håvard, Tanja Ellingsen, Scott Gates and Nils Petter Gleditsch. 2001. "Toward a democratic civil peace? Democracy, political change, and civil war, 1816-1992." American Political Science 
Review 95(1):33-48.

Hobbes, Thomas. 1991. Leviathan. Cambridge: Cambidge University Press.

Horowitz, Donald L. 1993. "Democracy in divided societies." Journal of Democracy 4(4):18-38.

Houle, Christian. 2009. "Inequality and democracy: Why inequality harms consolidation but does not affect democratization." World Politics 61(4):589-622.

Huang, Reyko. 2016. The wartime origins of democratization: civil war, rebel governance, and political regimes. Cambridge: Cambridge University Press.

Humphreys, Macartan and Jeremy M. Weinstein. 2006. "Handling and manhandling civilians in civil war." American Political Science Review 100(3):429-447.

Huntington, Samuel P. 1968. Political order in changing societies. New Haven: Yale University Press.

Joshi, Madhav. 2010. "Post-civil war democratization: promotion of democracy in post-civil war states, 1946-2005." Democratization 17(5):826-855.

Joshi, Madhav. 2013. "Inclusive institutions and stability of transition toward democracy in postcivil war states." Democratization 20(4):743-770.

Keele, Luke. 2010. "Proportionality difficult: Testing for nonproportional hazards in Cox models." Political Analysis 18(2):189-205.

Kisangani, Emizet F. and Jeffrey Pickering. 2007. Military intervention, 1989-2005. download: Ann Arbor, MI: Inter-university Consortium for Political and Social Research: Kansas State University.

Knack, Steven and Philip Keefer. 1995. "Institutions and economic performance: Cross-country tests using alternative measures." Economics and Politics 7(3):207-227.

Kreutz, Joakim. 2010. "How and when armed conflicts end: Introducing the UCDP conflict termination dataset." Journal of Peace Research 47(forthcoming).

Levitsky, Steven and Lucan A Way. 2010. Competitive authoritarianism: Hybrid regimes after the Cold War. Cambridge: Cambridge University Press.

Lijphart, Arend. 1994. Electoral systems and party systems: A study of twenty-seven democracies, 1945-1990. Oxford: Oxford University Press.

Linz, Juan J. and Alfred Stepan. 1996. Problems of democratic transition and consolidation: Southern Europe, South America, and Post-Communist Europe. Baltimore: Johns Hopkins University Press. 
Lipset, Seymour Martin. 1959. "Some social requisites of democracy: Economic development and political legitimacy." American Political Science Review 53(1):69-105.

Maddala, G. S. 1983. Limited-dependent and qualitative variables in econometrics. Cambridge: Cambridge University Press.

Mozaffar, Shaheen, James R. Scarritt and Glen Galaich. 2003. "Electoral institutions, ethnopolitical cleavages, and party systems in Africa's emerging democracies." American Political Science Review 97(3):379-390.

Mukherjee, Bumba. 2006. "Why political power-sharing agreements lead to enduring peaceful resolution of some civil wars, but not others?" International Studies Quarterly 50(02):479-504.

O’Donnell, Guillermo and Philippe C. Schmitter. 1986. Transitions from authoritarian rule: Tentative conclusions about uncertain democracies. Baltimore: Johns Hopkins University Press.

Olson, Mancur. 1993. "Dictatorship, democracy, and development." American Political Science Review 87(3):567-576.

Ordeshook, Peter C. and Olga V. Shvetsova. 1994. "Ethnic heterogeneity, district magnitude, and the number of parties." American Journal of Political Science 38(1):100-123.

Padró i Miquel, Gerard. 2007. "The control of politicians in divided societies: The politics of fear." The Review of Economic Studies 74(4):1259-1274.

Pearson, Frederic S. and Robert A. Baumann. 1992. Military intervention, 1946-1988. download: Ann Arbor, MI: Inter-university Consortium for Political and Social Research: University of Missouri-St. Louis, Center for International Studies.

Posner, Daniel N. 2004. "Measuring ethnic fractionalization in Africa." American Journal of Political Science 48(4):849-863.

Przeworski, Adam. 1991. Democracy and the market: Political and economic reforms in Eastern Europe and Latin America. Cambridge: Cambridge University Press.

Przeworski, Adam. 2005. "Democracy as an equilibrium." Public Choice 123:253-273.

Przeworski, Adam, Michael E. Alvarez, José Antonio Cheibub and Fernando Limongi. 2000. Democracy and development: Political institutions and well-being in the World, 1950-1990. Cambridge: Cambridge University Press.

Quiroz Flores, Alejandro. 2008. "Copula functions and bivariate distributions for survival analysis: An application to government survival." NYU Department of Politics Working Paper. 
Regan, Patrick M., Richard W. Frank and David H. Clark. 2009. "New datasets on political institutions and elections, 1972-2005." Conflict Management and Peace Science 26(3):286-304.

Reynal-Querol, Marta. 2005. "Does democracy preempt civil wars?" European Journal of Political Economy 21:445-465.

Riker, William H. 1986. The art of political manipulation. New Haven: Yale University Press.

Sartori, Giovanni. 1994. Comparative constitutional engineering: An inquiry into structure, incentives and outcomes. New York: Columbia University Press.

Schumpeter, Joseph A. 1976. Capitalism, socialism and democracy. 5th ed. London: George Allen and Unwin.

Sisk, Timothy D. 1996. Power sharing and international mediation in ethnic conflicts. Washington D.C.: United States Institute of Peace.

Taagepera, Rein and Matthew Shugart. 1989. Seats and votes: The effects and determinants of electoral systems. New Haven: Yale University Press.

Thelen, Kathleen and Steve Steinmo. 1992. Historical institutionalism in comparative perspective. In Structuring politics, ed. Steve Steinmo, Kathleen Thelen and Frank Longstreth. Cambridge: Cambridge University Press pp. 1-32.

Walter, Barbara F. 2004. "Does conflict beget conflict? Explaining recurring civil war." Journal of Peace Research 41(3):371-388.

Wantchekon, Leonard. 2004. "The paradox of "warlord" democracy: A theoretical investigation." American Political Science Review 98(01):17-33.

Wantchekon, Leonard and David Nickerson. 1999. Multilateral intervention facilitates post-civil war democratization. Yale University: Working Paper.

Wantchekon, Leonard and Zvika Neeman. 2002. "A theory of post-civil war democratization." Journal of Theoretical Politics 14:439-464.

Weidmann, Nils. 2009. "Geography as motivation and opportunity: Group concentration and ethnic conflict." Journal of Conflict Resolution 53(4):526-543.

Wilde, Joachim. 2000. "Identification of multiple equation probit models with endogenous dummy regressors." Economics Letters 69(3):309-312.

Nils W. Metternich: Department of Political Science

Current address: University College London, London, UK

E-mail address: n.metternich@ucl.ac.uk 